\title{
Historical tsunamis in the Concepcion bay, as seen in the reconstructed flood levels from the colonial city of Concepcion (Penco), Chile (1570-1835)
}

\author{
Tsunamis históricos en la bahía de Concepción, como se ve en los niveles de inundación \\ reconstruidos de la ciudad colonial de Concepción (Penco), Chile (1570-1835)
}

Daniel M. Stewart ${ }^{* *}$

\section{Resumen:}

Este paper utiliza información histórica recogida de cartas, informes y casos judiciales contemporáneos para reconstruir los niveles de inundación históricas para los tsunamis en la ciudad colonial de Concepción, Chile. Los niveles de inundación se analizan por forma individual para los tsunamis de 1570, 1575, 1657, 1730, 1733, 1751 y 1835. Las descripciones de la inundación de estos eventos históricos permiten que se los pueda comparar con el reciente terremoto de Maule 2010, que también generó un tsunami en la bahía de Concepción.

Palabras Claves: Terremoto, tsunami, Concepción, Penco, Colonial

\section{Abstract:}

This paper uses historical data from letters, reports, and contemporary court cases to reconstruct historical tsunami flooding levels in the colonial city of Concepcion, Chile. Individual flood levels are analyzed for the 1570,1575, 1657, 1730, 1733, 1751, and 1835 tsunamis. These individual reports allow for clear size comparisons between themselves and a realistic contrast with the recent 2010 Maule earthquake that generated a tsunami in the Concepcion Bay.

Key Words: Earthquake, tsunami, Concepcion, Penco, colonial, runups

Recibido: marzo 2019

Aceptado: octubre 2019

\footnotetext{
* This study was supported by the Millennium Scientific Initiative (ICM) of the Chilean government through grant NC160025 "Millennium Nucleus CYCLO The Seismic Cycle Along Subduction Zones".

** Postdoctoral Investigator for the Pontificia Universidad Católica de Valparaíso. Millennium Nucleus The Seismic Cycle Along Subduction Zones, Valdivia, Chile, (danielmoroni@hotmail.com).
} 


\section{Introduction}

The detailed study of Chilean earthquakes and tsunamis can be traced back to the turn of the twentieth century with the publication of the series Historia Sismica, by Fernand de Montessus de Ballore ${ }^{1}$. In six volumes he analyzed historically each of Chile's known earthquakes between the arrival of Pedro de Valdivia and the great Valparaiso earthquake of 1906. In his research, he scoured the Chilean and Spanish archives for related documents and enlisted the help of many of Chile's contemporary historians to find references for even the smallest earthquakes. His work provided the historical base for all future Chilean seismic studies.

In the years following the destructive 1960 Valdivia earthquake, new seismic catalogs for historical Chilean earthquakes were created by Cinna Lomnitz ${ }^{2}$ and refined with new Spanish archive data by Agustin Udias ${ }^{3}$. While each catalog greatly advances the scientific analysis started by Fernand Montessus de Ballore, they represent a decontextualized historical view of the seismic events within Chilean history. This is further seen in inaccurate statements about historical events leading up to the earthquakes themselves or the simple confusion of geographical locations mentioned in the historical documents they cited. Many of these problems were confronted and some cases fixed by Sergio Ruiz in his analysis of the Chilean earthquake sequence ${ }^{4}$.

From a historical vantage point, there has also been a renewed study of Chilean colonial earthquakes. Jaime Valenzuela published Jesuit letters and firsthand reports on the 1647 and 1730 earthquakes, with an analysis of the events mentioned therein ${ }^{5}$. His work was expanded

\footnotetext{
${ }^{1}$ Montessus de Ballore, Fernand, 1911. Historia sísmica de los Andes Meridionales al sur del paralelo XVI. Primera parte. Imprenta Cervantes, Santiago, 345 pp; 1912a. Historia sísmica de los Andes Meridionales al sur del paralelo XVI. Segunda parte. Imprenta Cervantes, Santiago, 236pp; 1912b. Historia sísmica de los Andes Meridionales al sur del paralelo XVI. Tercera parte. Imprenta Cervantes, Santiago, 86 pp; 1912c. Historia sísmica de los Andes Meridionales al sur del paralelo XVI. Cuarta parte. Imprenta Cervantes, Santiago, 213 pp; 1915. Historia sísmica de los Andes Meridionales al sur del paralelo XVI. Quinta parte, El terremoto del 16 de agosto de 1906. Sociedad Imprenta-Litografía "Barcelona", Santiago-Valparaíso, 407 pp; 1916. Historia sísmica de los Andes Meridionales al sur del paralelo XVI. Sexta parte, Adiciones. Sociedad Imprenta-Litografía "Barcelona", Santiago-Valparaíso, 85 pp.

2 Lomnitz, Cinna, 1970. Major earthquakes and tsunamis in Chile during the period 1535 to 1955. International Journal of Earth Sciences 59, 938-960; Lomnitz, Cinna, 2004. Major earthquakes of Chile: a historical survey, 15351960. Seismological Research Letters 75, 368-378.

3 Udías Agustin, Madariaga Raul, Bufon Elisa, Muñoz Daniela, Ros Manuel, 2012, "The large Chilean historical earthquakes of 1647, 1657, 1730, and 1751 from contemporary documents", in Bulletin of the Seismological Society of America, Vol. 102, No. 4, pp. 1639-1653, August 2012, DOI: 10.1785/0120110289.

4 Ruiz Sergio \& Madariaga Raul, 2018, "Historical and recent large megathrust earthquakes in Chile", in Tectonophysics, DOI: 10.1016/j.tecto.2018.01.015.

${ }^{5}$ Valenzuela Jaime, (2012), Relaciones jesuitas del terremoto de 1730: Santiago, Valparaíso y Concepción, Cuadernos de Historia, 37, Santiago, 2012, 195-224; Valenzuela Jaime, "El terremoto de 1647: experiencia apocalíptica y representaciones religiosas en Santiago colonial", en Jaime Valenzuela (editor), Historias urbanas. Homenaje a Armando de Ramón (Santiago, Ediciones Universidad Católica de Chile, 2007), pp. 26-65.
} 
upon by Mauricio Onetto ${ }^{6}$ and Alfredo Palacios ${ }^{7}$ who over the last decade have published sourcebooks and historical descriptions of most of Chile's earthquakes. Their work has mainly been focused on the history of disasters, with earthquakes and tsunamis being two of the most prevalent in Chile.

While the Chilean historians have been able to locate new source material for many of Chile's largest earthquakes, their publications have not been used by the scientific community. The notable disconnect between the historic and scientific communities is in large part due to the diverging focuses that each place on the analysis of the seismic event. While the historians are generally interested in the social and economic realities that an earthquake or tsunami cause on society, the scientific community's interests are focused on learning the specific geological or morphological characteristics of the seismic event that allows them to compare it to a more recent analog. They view each event as part of a repeating cycle that needs to be studied to be better prepared in the present.

Alliances between the scientific and historical communities have led to advances in our understanding of the $1580^{\circ}, 1730^{\circ}$, and $1737^{10}$ Chilean earthquakes. This paper is an example of such an alliance as it uses newly analyzed historical documents, from a unique historical vantage point, to accurately recreate the urban flooding levels for seven tsunamis that were present in the Concepcion Bay between the years 1570 and 1835. As mentioned, while most of these tsunamis and their related earthquakes have previously been studied by historians and scientists alike, none have used the now available historical information to pinpoint specific buildings or properties, affected or not affected, by a given tsunami within the early colonial port city of Concepcion, that until 1751 was located in the present-day site of the city of Penco.

Analyzing seven different tsunamis that affected the same specific location allows us not only to make relevant visible size comparisons but at the same time opens the door to future

${ }^{6}$ Onetto Mauricio, “Entre aporías espaciales y sentidos náufragos: El terremoto de 1647 como catalizador de percepciones y asimilaciones históricas", en Nuevo mundo, mundos nuevos, No 7 (París, 2007); Onetto Mauricio, Temblores de tierra en el jardín de edén. Desastre, memoria e identidad: Chile, siglo XVI-XVIII. Santiago, DIBAM, Centro de Investigaciones Diego Barros Arana, 2007.

7 Palacios Roa Alfredo, Fuentes para la historia sísmica de Chile (1570-1906), estudio preliminar, selección, transcripción y notas, Fuentes para la historia de la República Volumen XLI, DIBAM, Chile, 2016; Palacios Roa Alfredo, Sismicidad histórica de la ciudad de Concepción desde su fundación en 1550 hasta su traslado en 1751, Servicio Nacional de Geología y Minería, Chile, Boletín, No. 64, año 2012.

8 Cisternas, Marco., Fernando Torrejón, and Nicolas Gorigoitia (2012). Amending and complicating Chile's seismic catalog with the Santiago earthquake of 7 August 1580, J. S. Am. Earth Sci. 33, 102-109.

${ }^{9}$ Urbina Ximena, Nicolas Gorigoitía, and Marco Cisternas (2016), Aportes a la historia sísmica de Chile: El caso del gran terremoto de 1730 [in Spanish], Anu. Estud. Am., 73(2), 657-687.

${ }^{10}$ Cisternas Marco, Carvajal Matias, Wesson Rob, Ely Lisa, and Gorigoitia Nicolas, 2017, "Exploring the Historical Earthquakes Preceding the Giant 1960 Chile Earthquake in a Time-Dependent Seismogenic Zone", in Bulletin of the Seismological Society of America, Vol. 107, No. 6, pp. 2664-2675, December 2017, doi: 10.1785/0120170103. 
mathematical modulation, connecting flood data from this investigation with similar information from other points along the Chilean and Japanese coasts ${ }^{11}$. Such mathematical models will permit the scientific community to analyze these historical seismic events with the same criteria as those of a more recent date.

Locating the flood levels from each historical tsunami formed part of a larger investigation whose focus was on creating a detailed urban map of the colonial city of Concepcion showing where not only the civic and religious buildings were located, but also who lived in each of the cities nearly fifty urban blocks. The investigation into the city's inhabitants, located dozens of unknown colonial court cases and reports centered around the reconstruction of the city after each tsunami. This new information, connected with known colonial earthquake reports, that in themselves sometimes mention specific landowners by name, allows us to now recreate where the tsunami's waves reached and specific water depths in several key locations throughout the city.

The accumulation of tsunami and earthquake specific data for the city of Concepcion acquired during this investigation has also allowed us to discard three suspected tsunamis as not existing or simply not being present in Concepcion $(1562,1647,1746)$, while adding two tsunamis to Concepcion's known sequence $(1575,1733)$. That said, this paper will provide specific details about the size, flooding, and damage from the 1570, 1575, 1657, 1730, 1733, 1751 , and 1835 tsunamis in the city of Concepcion, located in the present-day city of Penco. Each data point will be marked on the city's only detailed colonial map, while the GPS locations will be included in appendixes to this paper. We can use the colonial map as our guide because the reconstructed nineteenth-century city of Penco retained the colonial city's grid layout and street locations. Lastly, these historical tsunamis can be compared to the recent 2010 Maule earthquake, whose corresponding tsunami was recorded in the same geographic location as those studied in this paper.

The city of Concepcion was founded in 1550 on the shore of the Concepcion Bay in the small valley formed by the Penco River. While Indian uprisings destroyed the town twice during the $16^{\text {th }}$-century, colonial documentation in the form of chronicles, reports, administrative papers, and court documents continually existed from its founding to the present day. Any significant earthquake or tsunami was and would have been recorded first by local officials in their letters to Lima, Santiago, or Spain and second by the city's or region's inhabitants during the reconstruction process.

\footnotetext{
${ }^{11}$ Carvajal Matias, Cisternas Marco, Catalán Patricio, 2017, Source of the 1730 Chilean earthquake from historical records: Implications for the future tsunami hazard on the coast of Metropolitan Chile", Journal of Geophysical Research: Solid Earth, 122, 3648-3660, doi:10.1002/ 2017JB014063.
} 
Many historical and scientific papers refer to the destruction of Concepcion's colonial archives as a delimiting factor in historic seismic investigations. They fail to recognize the vast amount of historical information that was sent to Santiago, Lima, and Madrid, that when used correctly fills in the gaps in the local historical record. Any notion that a significant tsunami could have occurred and gone unrecorded within the colonial period in this region is unfounded as is the assumption that all reports from the known seismic events have previously been located. The absence of historical documentation referring to a tsunami having occurred after a specific earthquake can and should be taken as definitive proof that no significant tsunami occurred while allowing for the remote possibility that a diminutive one went undetected. For reasons of clarity in this paper, we will analyze the complete historical seismic sequence for the Concepcion region and the complete tsunami sequence, which are not the same.

\section{October $28^{\text {th }}, 1562$}

This earthquake appears in several European books published around the turn of the $17^{\text {th }}$ century. In the Chilean documentation, the Spanish military historian, Alonso Gonzalez de Najera mentions Chile's first earthquake was in Concepcion in $1562^{12}$. The European publications put the earthquake and a connected tsunami off the coast of Arauco on October $28^{\text {th }}, 1562^{13}$. However, a closer look at the European publications shows that their descriptions of the quake are taken from an unsigned report of the 1575 Valdivia earthquake. At the same time, Alonso Gonzalez de Najera wrote his chronicle or treatise on the Chilean Indian war upon his return to Spain, drawing upon local published reports to fill in the cultural gaps. He clearly states that Concepcion was destroyed by Chile's first historical earthquake and that Valdivia was destroyed by the second.

No local documentation in Chile or the Spanish archives refers to the 1562 earthquake or tsunami. However, some local officials paraphrased the same description used to describe the 1562 event when talking about the large earthquake that predated the 1647 destruction of Santiago. Therefore, we concur with the Chilean historian Thayer Ojeda in suggesting that this seismic event simply never occurred.

\footnotetext{
12 Alonso Gonzales de Najera only spent a few years in Chile before returning to Spain to finish his book and lobby for military benefits for the Spanish army in Chile. Therefore, while it is clear that Concepcion was destroyed by a large earthquake accompanied by tsunami before he arrived in 1602, the 1562 earthquake likely refers to the widely reported Hispaniola earthquake that occurred on December $2^{\text {nd }}, 1562$.

${ }^{13}$ The original source of this misinformation can be attributed to the Jesuit Historian Jose de Acosta who in 1590 published the book Historia natural y moral de las Indias, where he describes a great Chilean earthquake, whose date he did not remember (chapter XVI). Subsequent Italian authors gave the earthquake a date and a location off the coast of Arauco.
} 


\section{February 8th, 1570}

All Chile's colonial historians agree that Chile's first major earthquake and tsunami destroyed the city of Concepcion. As mentioned, Gonzalez de Najera placed the quake in 1562, while another contemporary author Alonso Gongora Marmalejo dates it to 1568. However, the specific administrative documentation, cited in other chronicles and found in court and civic documents, places the quake on February 8th, 1570, which happened to be the Catholic holiday of "Ash Wednesday".

Two firsthand chronicles and a series of letters and reports document what occurred during the earthquake and tsunami and in the weeks and months that followed. Furthermore, several 17 th and 18th-century historians used now nonexistent sources to describe the earthquake and the tsunami's destruction.

Unfortunately for this event, we are hampered in our attempts to described the overall size of the quake itself, by the effects of an ongoing Indian uprising that had led to the abandonment only months earlier of the coastal towns of Cañete (Lebu) and Arauco and the interior town of Angol, all of which would have been within the general destruction radius of the earthquake and in the case of Arauco and Lebu the path of the tsunami. What we can say is that no significant earthquake damage occurred in Valdivia to the south or Santiago to the north and that the tsunami reports were limited only to the bay of Concepcion. The only account that we have of earthquake damage outside of Concepcion, comes from the governor Melchor Bravo de Saravia, who was camped near the Laja river with his soldiers. Upon feeling the quake, he decided to march to the rescue of the city of Concepcion, where the Royal Court was located.

Colonial chronicles report that the quake occurred around 9 AM and caused numerous water and sulfur geysers to appear in and around the city of Concepcion. The town's inhabitants were forewarned of the quake by a large noise that came from the south. The main shock lasted for a couple of minutes, with large and constant aftershocks over the next six months ${ }^{14}$.

Nearly an hour after the mainshock, the water receded out of the Concepcion Bay and the first of three large waves ingulfed what was left of the city. Each of the chronicles is clear on two things first that during the earthquake and tsunami all of Concepcion's buildings were destroyed and second that the tsunami's waves reached the hills surrounding the city ${ }^{15}$. The only building that we have confirmed not to have been reached by the tsunami was the Franciscan convent located on a hill on the northeast edge of town, which nonetheless was destroyed by the quake. That said, the descriptions of the waves cresting the hills that

\footnotetext{
${ }^{14}$ Carvallo Goyeneche, Santiago Vicente.1875. Colección de Historiadores de Chile, documentos a la Historia Nacional Tomo IX, Descripción Histórico-Jeografica del reino de Chile, tomo 1, pages 173-175.

${ }^{15}$ Mariño de Lovera, Pedro. 1865. Colección de Historiadores de Chile y documentos relativos a la Historia Nacional, Tomo VI, Crónica del Reino de Chile, p. 327.
} 
surrounded the city, and not just the hill that was directly above the plaza leads us to place the flooding for this tsunami far inland at the base of the hills on the edges of town. One fragmented historical confirmation of this flood level can be seen in the internal books for the Merced Convent, located in the peripherical upper reaches of the valley, which start in 1571 and not 1550 when it was built in Concepcion ${ }^{16}$.

Further clues to the nature of the earthquake and size of the tsunami are given by colonial historians Pedro Mariño de Lovera and Diego de Rosales who state first that the tsunami formed a large long-lasting lagoon in the Cantarranas neighborhood and second that after the first (smaller) tsunami wave arrived, horses were seen swimming in the town's main plaza. That information first confirms that the waves reached the hills and second gives an estimated water depth in the plaza of between two and three meters. Lastly, the Jesuit historian Diego de Rosales informed his contemporary audience that the large 1657 tsunami that he experienced and wrote about was minuscule in comparison to the 1570 tsunami.

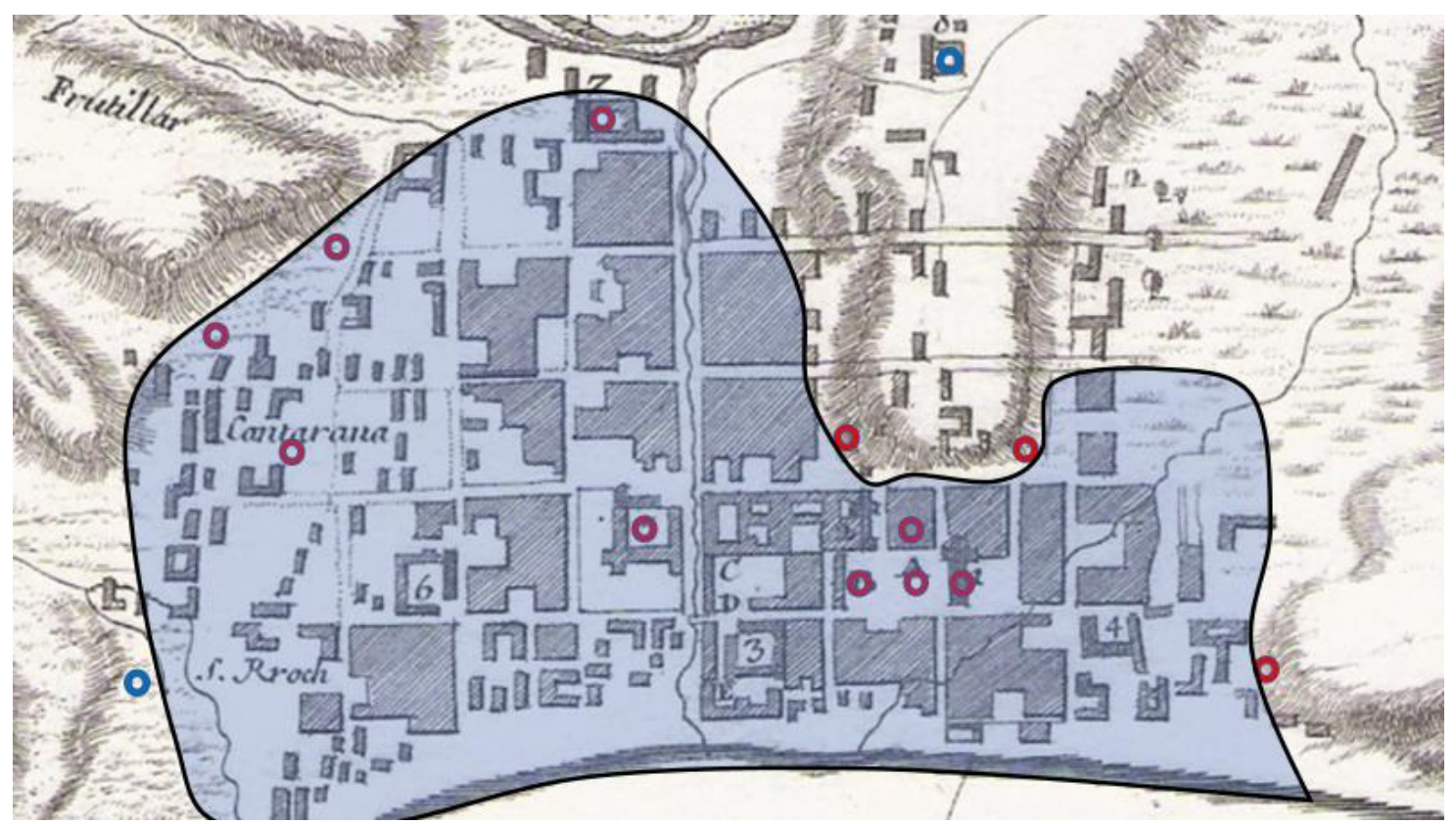

Figure 1: Calculated flooding levels from the 1570 tsunami with the location of historical sources. See appendix 1 for data point locations and source material.

\footnotetext{
${ }^{16}$ ANH.RA vol. 72, During a court case in 1663 the monks from the Merced Convent cited pages from their earliest archived material, which they stated started in 1571 and not 1550.
} 


\section{December $16^{\text {th }}, 1575$}

This second megathrust event has been heavily studied as a historical analog of the 1960 Valdivia earthquake. The main shock occurred on December $16^{\text {th }}, 1575$ around 3 PM. Local reports place the duration of the mainshock or shocks at around 15 minutes, with prior cyclones are other weather-related phenomena in the interior valleys of southern Chile.

While the main event occurred in or around the city of Valdivia, local colonial officials reported the complete destruction of the towns of Angol, Castro, Imperial, Osorno, Villarica, and Valdivia. In a letter to the Spanish King, Melchor Calderon, Chile's Vice-Governor, wrote that while all of the southern cities had been destroyed by the earthquake and that the city of Concepcion had only faced minimal earthquake damage since it was farther to the north.

While the destruction caused by the 1575 earthquake places it as one of the biggest if not the biggest Chilean historical earthquake, it pales to the level of destruction caused by the subsequent tsunami. Firsthand reports from Chiloe, Concepcion, Imperial, Tolten, and Valdivia describe the tsunami's destructive waves and the death and destruction it left behind. Melchor Calderon stated that while the earthquake did little damage to the rebuilt city of Concepcion the tsunami flooded everything.

That said, previous historical and scientific investigations have ignored Melchor Calderon's words, claiming that the city could not have been rebuilt from the 1570 tsunami and that any tsunami flooding would have been minimal since the 1960 analog did not produce a tsunami that adversely effected the city of Penco ${ }^{17}$. However, in 1581 a small written history of the Franciscan religious order in Chile relates how in 1572 the convent in Concepcion was relocated to the banks of the Penco River one full block from the beach. The author, who had been in charge of the Concepcion convent at that time retold what he referred to as a miracle, which was that during the tsunami created by the great earthquake of 1575 that the water reached the top of the convent's walls, but miraculously the water level stayed below the top of the main altar until the monks were able to enter the chapel and remove the sacred ornaments of the last super from their traditional place on top of the main altar.

The monk's description does not mention damage directly related to the earthquake, which confirms Melchor Calderon's description of the intensity of the quake in the city itself. The description of the water level on the walls of the convent would place the tsunami's depth at around $1.5-2.0 \mathrm{~m}$ at that location, which would be similar to the 1657 and 1730 tsunami runups. Therefore, new models for the 1575 earthquake will need to include a significant tsunami in Concepcion Bay.

\footnotetext{
${ }^{17}$ Cisternas Marco, Carvajal Matias, Wesson Rob, Ely Lisa, and Gorigoitia Nicolas. 2017. "Exploring the Historical Earthquakes Preceding the Giant 1960 Chile Earthquake in a Time-Dependent Seismogenic Zone", in Bulletin of the Seismological Society of America, Vol. 107, No. 6, pp. 2664-2675, December 2017, doi: 10.1785/0120170103.
} 


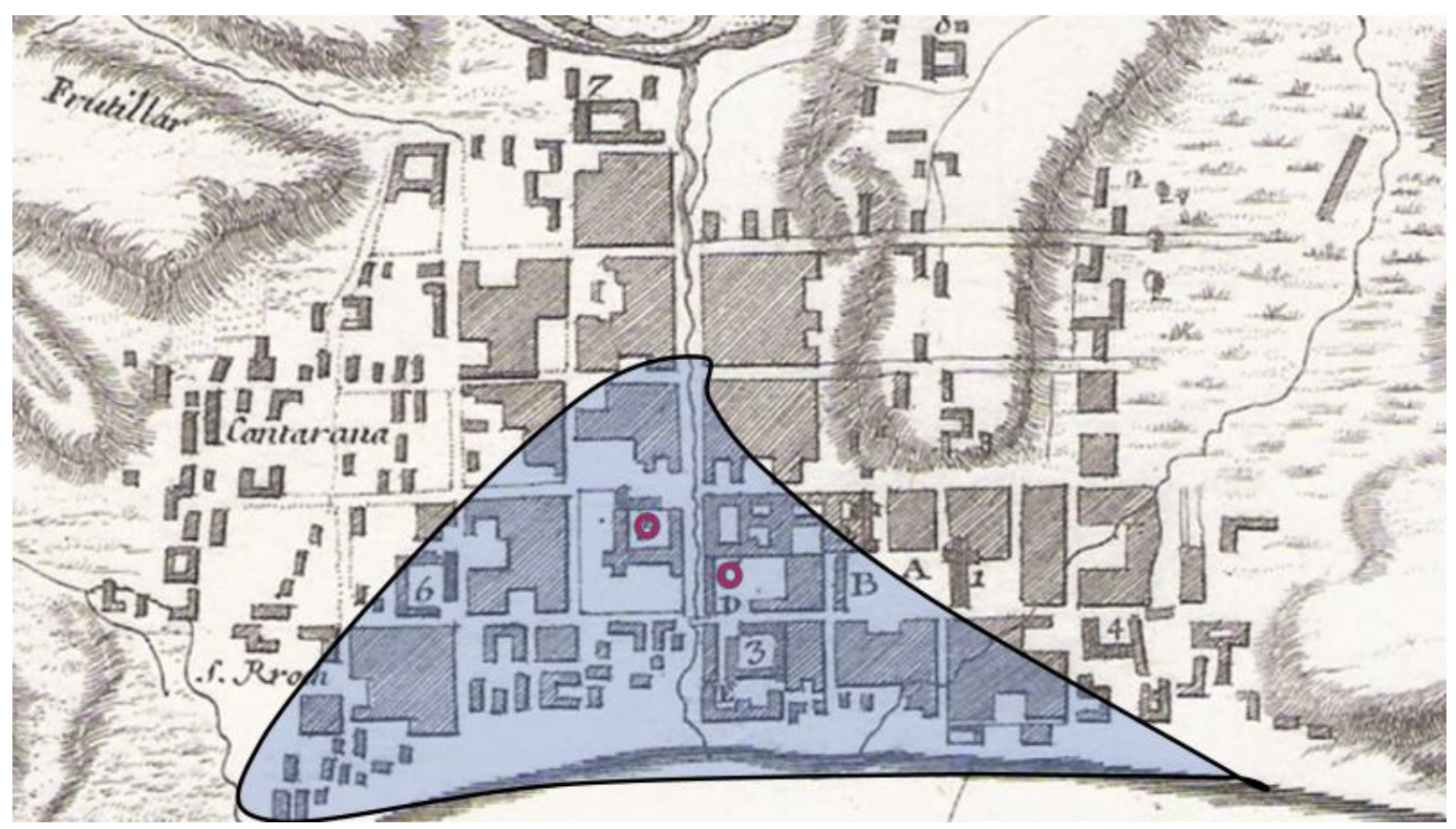

Figure 2: Calculated runups from the 1575 tsunami with the location of historical sources. See appendix 2 for data point locations and source material.

\section{May 13th, 1647}

This earthquake is one of Chile's least understood from a scientific vantage point. While the earthquake's destruction was notoriously devasting in the city of Santiago, where thousands died in the quake itself and subsequent weather and illness-related catastrophes, its characteristics outside the city are not well-known. That said, the quake's geographical area of highest intensity might have reached as far south as the Maule River.

At the time of the earthquake, Martin de Mujica, the Spanish Governor in Chile, was in Concepcion writing reports to be sent by boat to Lima. He was worried about recent peace accords signed between the Spanish and Indian populations and the need to expedite the resupply of the newly rebuilt military base in Valdivia, by ships now docked in the Valparaiso harbor. The reports were finished and dated on May $26^{\text {th }}, 1647$, nearly two weeks after the earthquake, without any mention of it whatsoever ${ }^{18}$.

Two days later, on May 28th, the first three reports from Santiago arrived in Concepcion. They were from the City Council, Real Audiencia, and the Catholic Bishop. Each described the massive destruction that had occurred in Santiago and their attempts to find short term

\footnotetext{
${ }^{18}$ Archivo General de Indias, CHILE,21,R.2,N.27
} 
solutions to the devastation. Included in the report by the Real Audiencia was a paragraph assuring the governor that while the buildings in the port of Valparaiso had been damaged by the earthquake, nothing had occurred to the ships or their cargo that would delay the resupply of Valdivia. At the time of the quake, one of the judges from the Real Audiencia was stationed in Valparaiso overseeing the loading of the supply ships. Since the bales and bags of supplies were stored directly on the beach during the loading process, even the slightest deviation in the water's depth would have damaged the supplies and assuredly would have been included in the initial or posterior damage reports.

In addition to the three letters from Santiago, two additional letters were sent to Lima from Concepcion that referred to the earthquake and the damage it caused. The first was an addition to the yearly administrative letter that the Jesuit friars sent to their superiors in Rome. The author, writing from the convent in Concepcion where the report was created, wrote about receiving a letter from the Jesuits in Santiago describing the earthquake and loss of their belongings in that city ${ }^{19}$. His own report indicated that he never felt the earthquake himself but decided to add an addendum to his report since the news of the earthquake had delayed the ship's departure. On the other hand, the governor stated that he had felt the quake and that while it had been long, that no damage whatsoever had occurred in the city. Any change in water levels would have been noted by the local officials, who would not have had time to react since their earthquake itself had not alarmed the population and was probably not felt by most of the city's inhabitants. Both reports make it very clear that the 1647 earthquake, while very large and destructive in Santiago itself, did not generate a tsunami in the bays of Valparaiso or Penco.

Later administrative reports linked the earthquake's destruction with the posterior loss of two merchants ships off the coast of northern Chile under strange circumstances ${ }^{20}$. However, the connection between the two events was only made as an explanation as to why the leading citizens of Santiago would not have any monetary resources to use in rebuilding the city. Furthermore, internal letters mention that criminal charges were pending against the Royal Judge who had allowed the boats to be overloaded, which in turn had made them unstable, thus causing their sinking.

\footnotetext{
19 1647, Letras Annuas de la Vice Provincia de Chile, Archivo Vaticano de Roma, Chile Vol. 6

${ }^{20}$ Valenzuela Jaime, "El terremoto de 1647: experiencia apocalíptica y representaciones religiosas en Santiago colonial”, en Jaime Valenzuela (editor) 2007., Historias urbanas. Homenaje a Armando de Ramón, Santiago, Ediciones Universidad Católica de Chile, pp. 26-65.
} 


\section{March 15th, 1657}

The next historical earthquake and tsunami that we have for the Bay of Concepcion occurred around 8:30 PM on March $15^{\text {th }}, 1657$. The main shock lasted for over four minutes and while the center of the quake was in or around the city of Concepcion, serious structural damage reached as far north as Santiago and Quillota and at least to Arauco in the south. The main shock was followed by months of aftershocks of varying length and strength. The earthquake's intensity in the city of Concepcion caused the immediate collapse of most of the city's structures. Churches, military warehouses, palaces, stores, and common homes were indiscriminately reduced to rubble. The only buildings that survived largely intact were a few homes built onto the hill above the plaza and the Jesuit chapel, located on the base of the same hill.

The main shock occurred while an already seasonally high tide was receding. Diego de Rosales states that the Penco River flooded its banks during the quake and cut off the northeastern side of the town. An hour later the water receded from the bay and the first of three large waves reached the city.

Unlike the two previous historical tsunamis, for this one, we have not only firsthand reports, chronicles and letters, but a series of posterior court cases centered around the city's irregular reconstruction process. They allow us to pinpoint 37 locations within the city that experienced earthquake damage. Of those, 31 reported tsunami flooding, while the other six specifically mentioned that they were not flooded. These data points allow us to draw a clear flood zone for this specific tsunami.

We are also able to add a series of water depths to the equation, which allows for a more detailed analysis. First, multiple reports indicated that a merchant ship of unknown size was beached by the tsunami's first wave on the roof of the San Agustin Convent. The second wave then refloated the boat and deposited it into a lagoon that formed in the Cantarranas neighborhood, similarly as in the 1570 tsunami. This description places the water's depth at that location at a minimum of 3 to 4 meters. The height at the San Agustin convent also allows to expand the flood levels in the sparsely populated Cantarranas neighborhood.

The second series of locations where we have water depths are in the main plaza and cathedral. Diego de Rosales and others inferred that the water covered only half of the plaza. Civil court cases show that while the upper limits of the plaza might have survived the brunt of the waves, they were still reached by the water itself. As shown by reports of water entering the Jesuit Chapel and Lazaro San Martin's stores, both of which were located on the upper edge of the plaza.

The cathedral was severely damaged by the earthquake, causing a partial collapse of the main building itself. The colonial historian Vicente Carvallo Goyeneche and posterior judicial documents describe the earthquake and tsunami damage that the building suffered. They 
explain that the water entered into the cathedral through the main doors at a depth of 1.5 meters at the lower end and $30 \mathrm{~cm}$ at the upper far end of the cathedral, where the sacred image of the Virgen was miraculously preserved. Furthermore, Diego de Rosales described how the tsunami completely flooded the city's newly built defensive military installations located around the main palace.

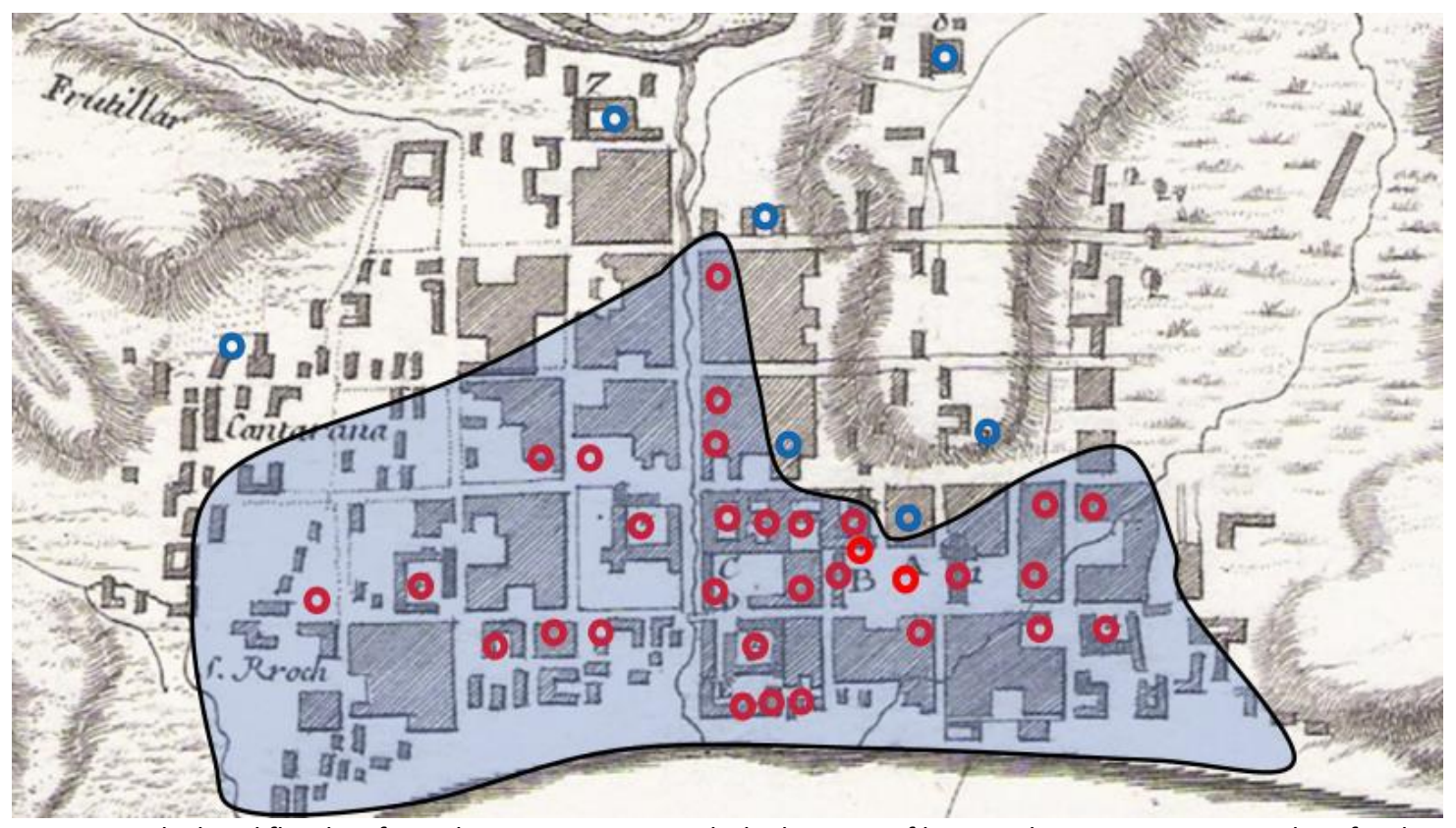

Figure 3: Calculated flooding from the 1657 tsunami with the location of historical sources. See appendix 3 for data point locations and source material.

July 8th, 1730

This megathrust earthquake has recently been studied by Matias Carvajal and Ximena Urbina was centered off the coast of Valparaiso, with a rupture zone characterized by serious structural damage to buildings stretching between Concepcion and La Serena ${ }^{21}$. A large foreshock was felt in Concepcion around $1 \mathrm{AM}$, while a much more powerful main shock occurred around $5 \mathrm{AM}$ causing a large tsunami.

The intensity of the two shocks caused structural damage in most of the city's buildings, but not at the same level as the 1657 earthquake. Most of the official damage reports refer to the destruction seen in the morning after the tsunami, while the first-hand accounts of the destruction refer almost entirely to the first tsunami wave.

\footnotetext{
${ }^{21}$ Urbina Ximena, Nicolas Gorigoitía, and Marco Cisternas .2016. Aportes a la historia sísmica de Chile: El caso del gran terremoto de 1730 [in Spanish], Anu. Estud. Am., 73(2), 657-687.
} 
Three detailed eyewitness damage reports reveal the location of lines of complete structural destruction left behind by the tsunami. One line started on the edge of the Penco River nearly four-hundred meters inland from the coast and cut east to the Cantarranas neighborhood. A second line started in the town plaza and went at a north-west angle to the beach. Local officials placed the tsunami's destruction at 190 buildings or two-thirds of the city. They included that the homes built around the Santo Domingo Convent were spared the wrath of the tsunami because they were at a higher elevation and that those around the Merced Convent were also spared because of the large distance inland they were from the coast. Through damage reports and posterior court cases, we have been able to identify 44 geographical markers within the city that suffered earthquake damage. Of those, 36 experienced tsunami flooding, which allows us to confirm the two mentioned tsunami damage lines and create a concise runup.

Two locations also provide us with recorded water depths. First, one of the tsunamis waves was recorded at a height of 10 varas $(8.2 \mathrm{~m})$ above the seasonal high tide. A second depth marker was recorded on the doors of the Jesuit Chapel, located above the main plaza, where the water reached the height of 1 vara $(0.8 \mathrm{~m})$. That second marker places the tsunami flooding at a slightly higher level than in 1657.

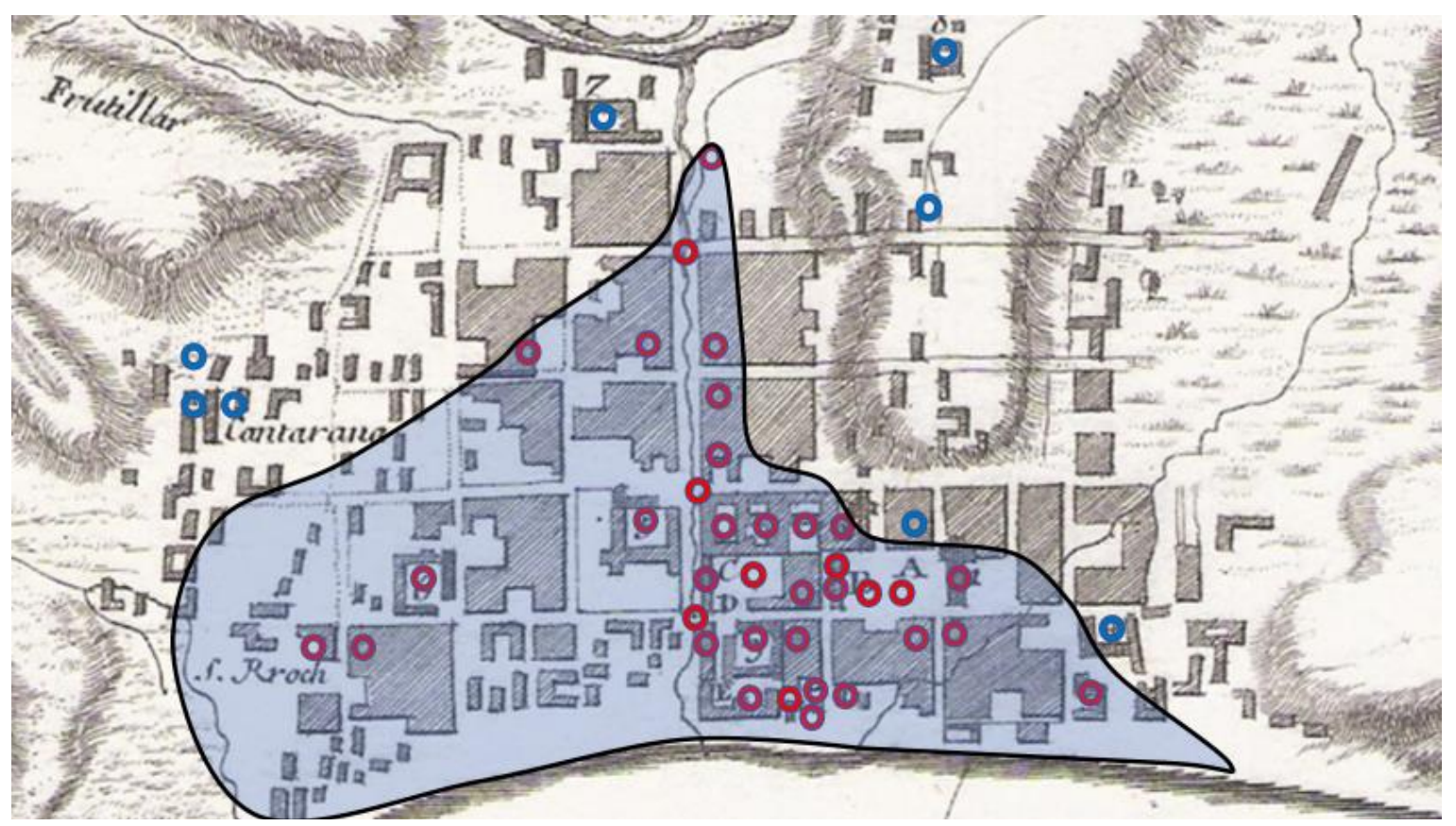

Figure 4: Calculated flooding from the 1730 tsunami with the location of historical sources. See appendix 4 for data point locations and source material. 


\section{May 24th, 1733}

This tsunami event was recently found in a petition sent to Santiago by the friars from the Concepcion Hospital, in an unsuccessful attempt to relocate the hospital from its prominent coastal location ${ }^{22}$. The idea of a missing tsunami, in effect is not new, as in 1752 some of the town's leading citizens reported that there had been three tsunamis, two destructive and one not destructive, in a twenty-one-year period between 1730 and $1751^{23}$. While some speculated that the third event referred to waves from the 1746 Callao tsunami, we can now say that that is not the case ${ }^{24}$.

On Pentecost's day 1733, an unusually high tide or orphan tsunami flooded the lower edges of Concepcion. Reports indicate that this event is not connected to local seismic activity or a storm event. The witnesses separated the event from the seasonally high tides by expressing that the flooding far surpassed what normally occurred on those days. A calculation of the tides for the week of May $24^{\text {th }}$ shows no abnormally high tides that can explain this flooding ${ }^{25}$.

The report cited flooding in and around the San Juan de Dios Hospital and as far inland as the kitchen and garden of the Franciscan Convent. The water followed the main roads cutting off the Cantarranas neighborhood from the rest of the town and entering the lower reaches of the plaza on the other side. The flooding caused a general alarm within the town and an immediate evacuation to the hills. The same report indicated that the force of the waves did not cause any structural damage to the Hospital and that apart from the drying and cleaning process that occurred over the next few weeks. The author's main concern was the panic that the episode caused in the general population who saw the arrival of a tsunami without a prior earthquake.

At this time, we are unable to pinpoint a Western Pacific seismic event as the probable cause for this flooding. That said, Maori folklore from the coastal villages of New Zealand might be able to provide oral indications of a possible South Pacific seismic source.

\footnotetext{
${ }^{22}$ ANH.CMI vol. 4364, pages 23-29v

${ }^{23}$ AGI, CHILE 146, pages 464-466.

${ }^{24}$ Udías Agustin, Madariaga Raul, Bufon Elisa, Muñoz Daniela, Ros Manuel. 2012. "The large Chilean historical earthquakes of 1647, 1657, 1730, and 1751 from contemporary documents", in Bulletin of the Seismological Society of America, Vol. 102, No. 4, pp. 1639-1653, August 2012, DOI: 10.1785/0120110289.

25 Personal communication from Matias Carvajal who used a computer program to show the tides for the Penco Bay for the week of May 24th 1733.
} 


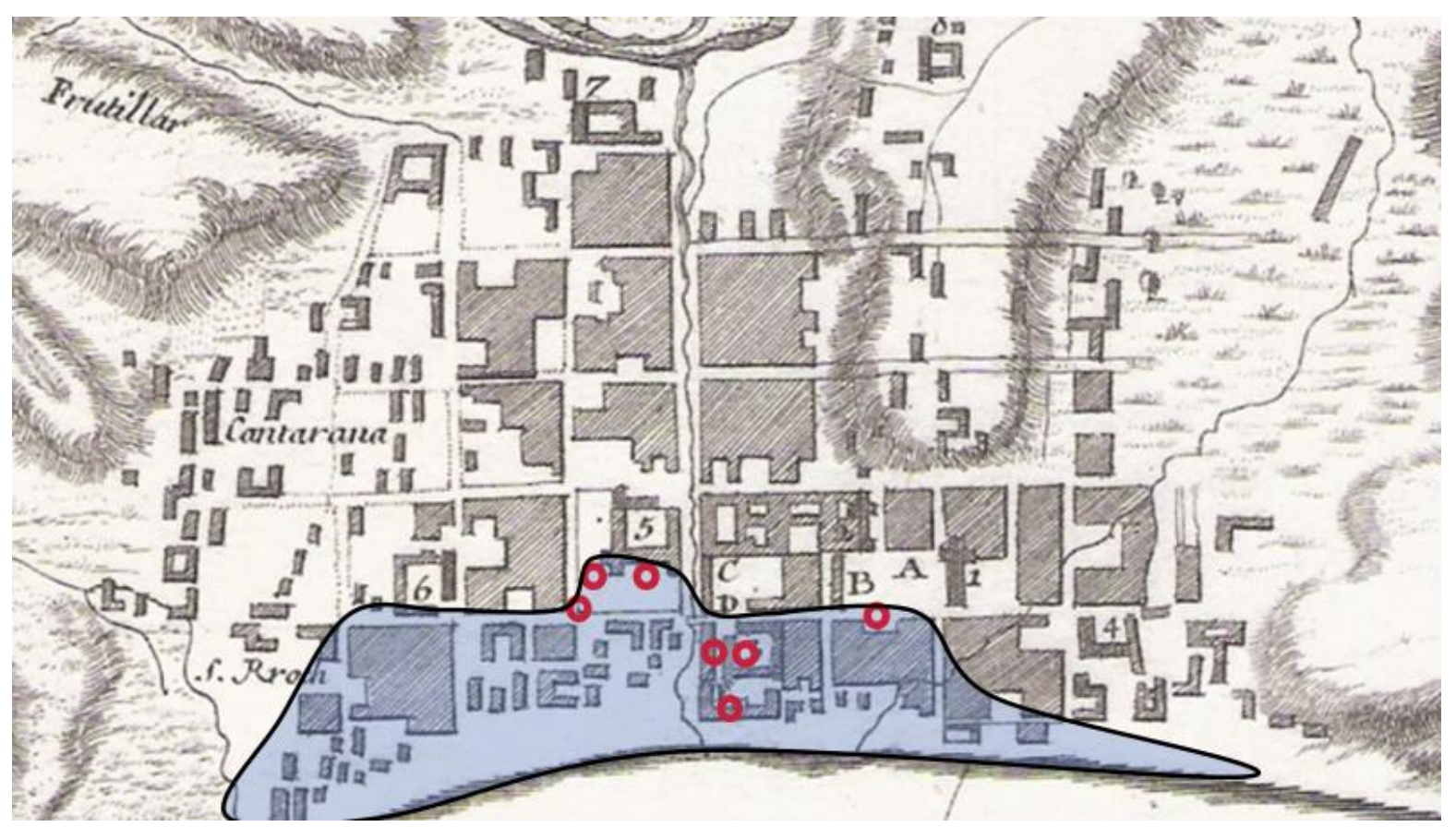

Figure 5: Reported flooding from the 1733 tsunami with the location of historical sources. See appendix 5 for data point locations and source material.

\section{May 25th, 1751}

This extremely large earthquake was centered off the coast of Concepcion. A large foreshock on the night of May 23rd, alarmed the city's residents and prepared them for future shocks. This first event was followed by a second powerful foreshock at 12:30 AM on the morning of May $25^{\text {th }}$, and a much larger mainshock 10 minutes later at 12:40 AM. The earthquake caused structural damages as far north as Santiago and Quillota and Valdivia to the south. The area of highest intensity was the region between the rivers Cachapoal and Cautin. Aftershocks were felt for months, with the largest occurring on the night of June $26^{\text {th }}$, which was described as being, as strong as the mainshock of May $25^{\text {th }}$, just not as long-lasting.

Local government officials in Concepcion recorded that the earthquake started around 12:30 AM and lasted for 22.5 minutes, during which time no one was able to remain standing, while a Jesuit priest noted that the mainshock lasted for 6 minutes and was the combination of six separate shocks or jolts. Eyewitness accounts and posterior official reports indicate, that the mainshock destroyed or severely damaged every building in the city ( 250 by most counts).

Around 30 minutes after the mainshock the water retreated completely out of the bay, returning seven minutes later in the first of a series of three large waves, the largest of which reached as far inland as the Merced Convent. The tsunami's waves left only twelve severely 
damaged buildings standing. Observers stated that the thrust of the waves removed most of the surviving portions of the city's buildings from their foundation stones, leaving them strewn throughout the valley. They also confirmed that the waves reached the base of the hills surrounding the city, similarly to the 1570 tsunami.

Reports and witness testimonies permitted us to locate 28 specific points within the city, 27 of which were reached by the tsunami. The location of the data points allows us to recreate a specific runup. A series of water depths and wave heights allow us to further characterize this tsunami. The last wave was recorded as being nearly 16 meters high by sailors in the bay. Later measurements showed that the water reached a height of at least 12 meters above the normal extreme high tides. A water depth of 3.4 meters was given for the plaza and the city in general. Above the plaza, the Jesuits recorded that the waves forced open their chapel's heavy wooden doors, ripping one off its hinges and depositing it hundreds of meters away on the beach. They recorded the destruction of their convent and a water height of 2.5 varas ( 2 meters) on the walls outside the chapel's doors. On the other side of the Penco River, at the recently rebuilt San Francisco Convent, a report stated that the water surpassed the ceiling of the interior rooms, which would indicate a height of at least three and a half meters.

While the city of Concepcion faced the brunt of the tsunami. Detailed reports of flooding and destruction are also available for Arauco, Bucalemu, Cahuil, Colcura, Juan Fernandez, and Valparaiso along the Chilean coast.

The earthquake and tsunami permanently changed the Penco landscape. The extremely important Penco anchorage was made unusable when previously unseen rocks and shoals appeared in the days after the quake. Decades later, several sea captains recorded that the anchorage was at least two meters shallower than it was in 1740 when the first detailed map was made of the bay ${ }^{26}$. The loss of the anchorage led to the forced relocation of the city to the Valley of Mocha, a few kilometers to the south.

\footnotetext{
${ }^{26}$ Juan, Jorge \& Ulloa, Antonio. 1748. Relación histórica del viaje a la América Meridional. Imprenta de Antonio Marín, 3 Vols. Madrid.
} 


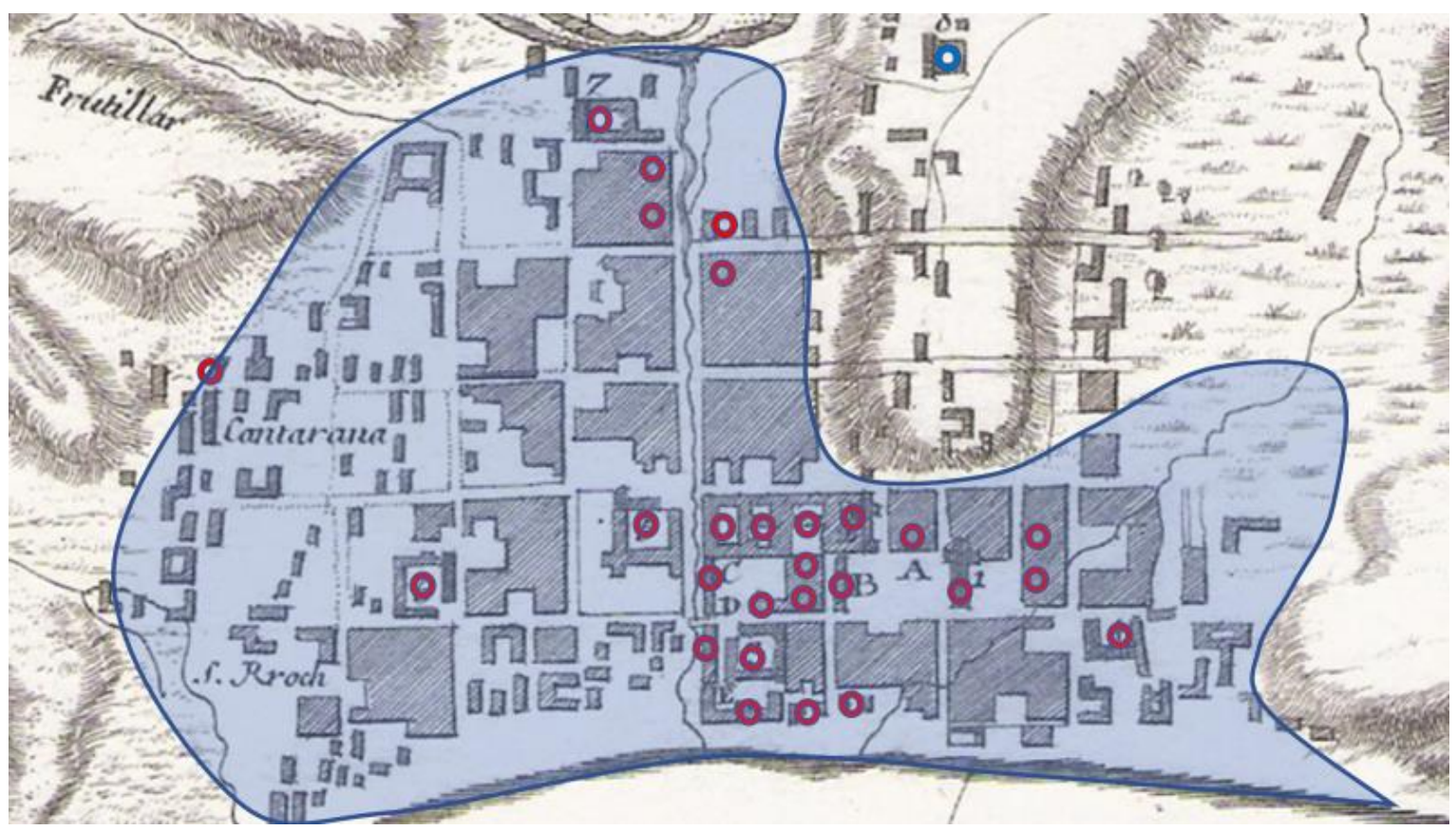

Figure 6. Reported flooding from the 1733 tsunami with the location of historical sources. See appendix 6 for data point locations and source material.

\section{February $20^{\text {th }}, 1835$}

Darwin's earthquake was felt between the islands of Chiloe and the mining town of Copiapo. The center of the quake was in and around the city Concepcion. Eyewitness accounts place the start of the quake at 11:40 AM. Capitan Fitz-Roy describes nearly a minute of medium shaking followed by six seconds of a massive jolt that caused all the buildings in the relocated city of Concepcion to fall to the ground. The severe shaking continued in irregular patterns for the next 2.5 minutes.

Witnesses in Talcahuano reported that thirty minutes after the mainshock, that the water receded from the bay and that a few minutes later the first of three waves crashed into the coast. Most contemporary witnesses centered their reports on the damage perceived in Concepcion, Talcahuano, San Vicente, and Valdivia, omitting the small village of Penco. Reports of coastal uplift were recorded for Talcahuano, and the Quiriquina and Santa Maria islands.

In and around the port of Talcahuano, at the entrance to the Concepcion Bay, tsunami wave heights of 12 and 15 meters were registered. While swells in the bay itself were recorded at 10 fathoms $(18 \mathrm{~m})$. Wave heights of 3.5 meters were reported at Tome and Dichato, further up the coast from Penco. While these wave heights were generally smaller than those from earlier tsunamis, Charles Darwin reported that the tsunami occurred at low tide, which in itself greatly reduced its damaged along the coast. 
While the ruined city of Concepcion in Penco was widely referred to in the damage reports from the 1835 quake, none of the authors reported what had occurred there during the quake itself. However, nearly three years after the earthquake in 1838 the French explorer Jules Dumont D'urville visited the village of Penco while exploring the coast of Chile ${ }^{27}$. While there he met with locals who he interviewed about the effects of the earthquake and tsunami on the landscape of the town. The ship's artist, Louis Le Breton recorded what he saw in a series of paintings.

While in Penco, they interviewed some of the locales, including a Frenchman named Mége, about the effects of the earthquake on the village. He mentioned that during the quake all but two buildings in the village were thrown to the ground and that the main shock lasted for nearly six minutes. He also mentioned that the strength of the mainshock was quite irregular, with large vertical and horizontal jolts.

He also mentioned that the village was overrun by the tsunami, whose first wave was measured at three meters higher than the seasonal high tide. On the other hand, when a second witness was asked about the coastal uplift recorded by Capitan Fitz-Roy, his reply was to state that in Penco the direct opposite had occurred. He explained that the height of the Spanish Coat of Arms on the outer wall of the Penco fort, that before the earthquake was beyond his reach was now easily accessible Furthermore, he stated that now the high tides reached the base of the fort, where in the past they had not. Their testimonies allow us to place six data points within the boundaries of the ruined city.

The coastal subduction in Penco, reported by Dumont D'urville, is possibly confirmed by secondary witnesses. Capitan Fitz-Roy wrote, "Women washing in the river near Concepcion were startled by the sudden rise of the water-from their ankles to their knees-and at the same moment felt the beginning of the convulsion." He further stated, "In a river near Lirquen, a woman was washing clothes at the time of the great shock. The water rose instantaneously, from her feet halfway up her legs; and then subsided gradually to its usual level. It became very muddy at the same time. On the sea-beach, the water swelled up to the high-water mark, at the time of the shock, without having previously retired" 28 .

\footnotetext{
${ }^{27}$ Dumont d'Urville, Jules, Voyage au pole sud et dans l'Oceanie, 1842, III.

${ }^{28}$ Sketch of the Surveying voyages of His Majesty's ships Adventure and Beagle, 1825-1836..., Journal of the Geological Society of London, vol. VI, part. II, p. 311-343.
} 


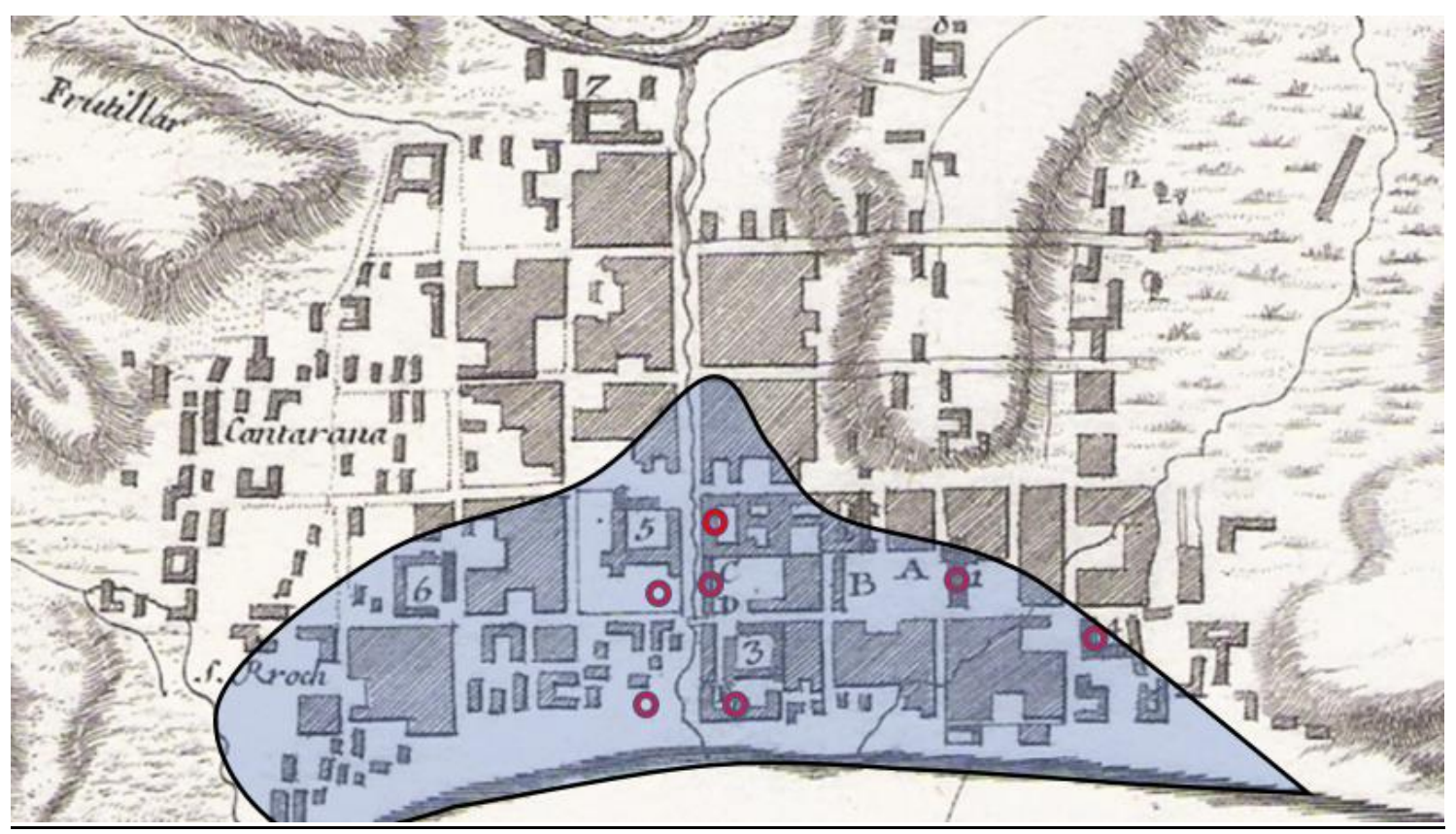

Figure 7. Calculated flooding from the 1835 tsunami in Penco. See appendix 7 for data point locations and source material.

\section{Discussion}

The recent 2010 Maule earthquake generated a tsunami that severely damaged the lower reaches of the present-day town of Penco. The recorded flooding for this tsunami places it in the middle of those analyzed in this paper. However, that is in part due to the construction, in the early twentieth century, of a railway line directly along the coast, which created a two to three-meter-high berm upon which the rails were laid. In 2010, the tsunami found ways to go under and over the now-abandoned railway bed, however without it, assuredly the water would have reached farther inland. 


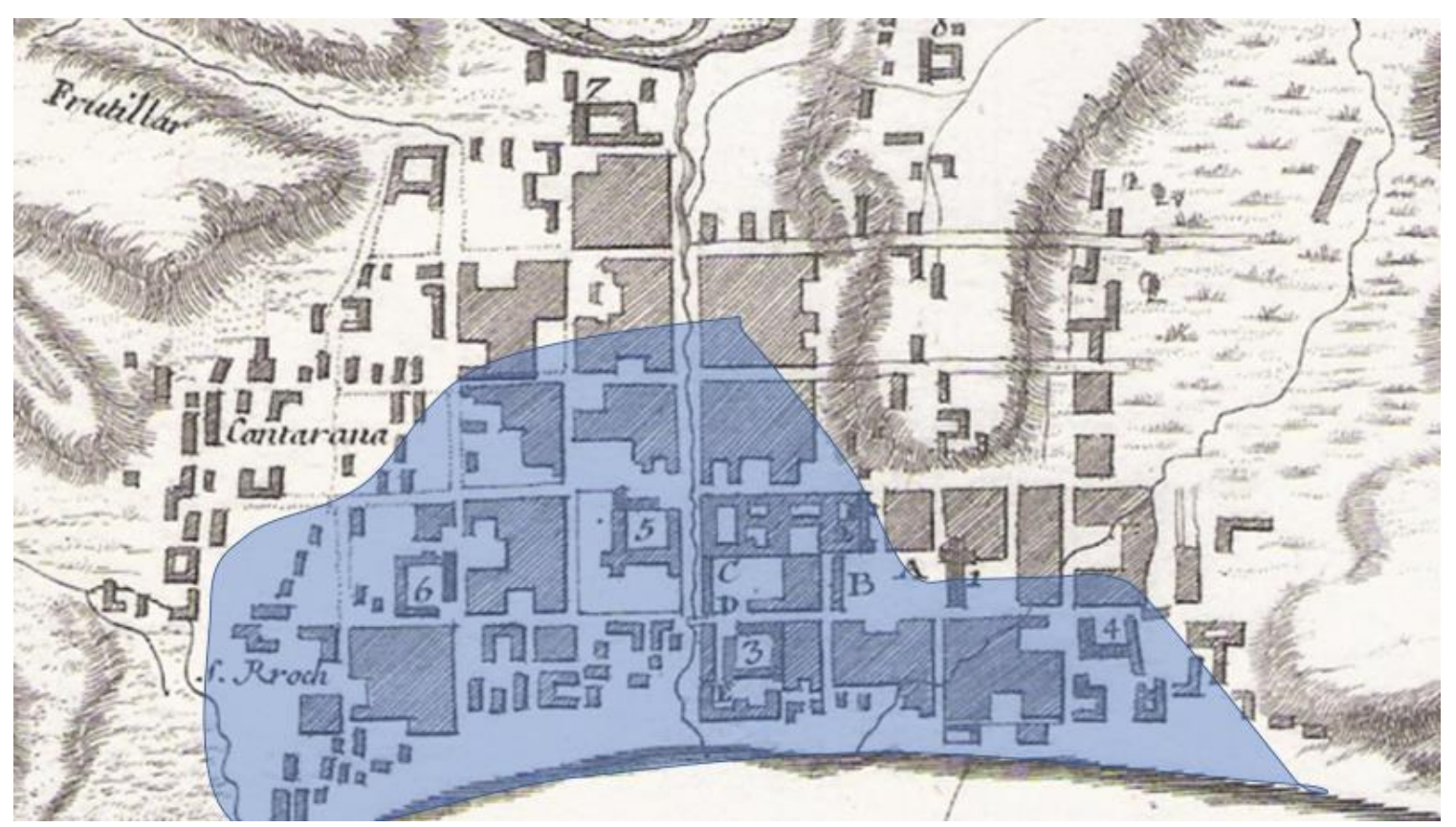

Figure 8. Flooding levels from the tsunami generated from the 2010 Maule earthquake as reported by the SHOA.

That said, the historical runups and water depths allow us to compare each of the tsunamis. For example, 1733 was the smallest recorded tsunami, followed by 1575 and then 1835 . Next, we have 1657 and 1730, and lastly, the two largest tsunamis 1570 and 1751, were the only ones known to have reached the upper levels of the Penco valley as seen in the location of the Merced Convent.

Water depths confirm this analysis as shown in the lower edge of the main plaza which was flooded in each of the seven recorded tsunamis. The four largest tsunamis at that location were 1657 ( 1.5 meters), 1730 (>2 meters), 1570 ( 3 meters), and 1751 ( 3.4 meters). The same pattern is seen on the upper edge of the plaza, where at least five tsunamis reached the entrance to the Jesuit Chapel. In 1570 and 1835, we know the water reached there, but at an unknown height. The three largest recorded were $1657(30 \mathrm{~cm}), 1730(80 \mathrm{~cm})$, and 1751 (2 meters).

The Concepcion Bay has suffered the effects of at least seven historical tsunamis. The recent 2010 tsunami, our best analog for the historical tsunamis, would at best be placed in the middle of the pack, alongside the 1657 tsunami. The individual historical tsunami runups along the Concepcion Bay combined with reported flooding from Japan and other inhabited points along the Chilean coast will allow future researchers to create mathematical models to explain the tsunami's characteristics. Those models coupled with vertical changes recorded along the coast and inland earthquake intensity levels, as seen in the damage suffered by colonial structures, will permit the creation of earthquake rupture models, that in turn will allow us to better 
understand the Concepcion subduction zone and its cyclical behavior within the overall Chilean subduction region.

\section{Sources and Bibliography}

\section{Sources}

AGI.Ch Archivo General de Indias (Sevilla), CHILE: vols. 21, 146, 146

ANA.NC Archivo Nacional de la Administración (Santiago de Chile), Notarios de Concepción: vols. 1

ANH.GAY Archivo Nacional Histórico (Santiago de Chile), Claudio Gay: vol. 18

ANH.ES

ANH.FV

Archivo Nacional Histórico (Santiago de Chile), Escribanos de Santiago: vol. 294

ANH.JES

Archivo Nacional Histórico (Santiago de Chile), Fondos Varios: vol. 258

ANH.RA

Archivo Nacional Histórico (Santiago de Chile), Jesuitas de Chile: vol. 71, 102

Archivo Nacional Histórico (Santiago de Chile), Real Audiencia: vols. 72, 80, 154, 240, $301,544,872,927,1188,1201,1290,1376,1466,1554,1591,1868,2201,2692$, 2468

ANH.CMI Archivo Nacional Histórico (Santiago de Chile) Contaduría Mayor I serie: vol. 4364

AVR Archivo Vaticano de Roma (Rome, Italy): vol. 5, 6

APD Archivo Provincial Dominico (Santiago, Chile): vol. 6

BN.MM Biblioteca Nacional de Chile (Santiago, Chile), Manuscritos Medina: 2712, 4268

AFC Archivo Franciscano de Chile, (publicaciones de fuentes): vol. 13, 15, 16

\section{Bibliography}

Acosta José, 2003 (1591), Historia natural y moral de las Indias, biblioteca virtual universal.

Carvajal M., Cisternas M., Catalán P. A., 2017, Source of the 1730 Chilean earthquake from historical records: Implications for the future tsunami hazard on the coast of Metropolitan Chile", Journal of Geophysical Research: Solid Earth, 122, 3648-3660, doi:10.1002/ $2017 J B 014063$.

Carvallo Goyeneche, Vicente. 1875. Descripcion Historico-Jeografica del reino de Chile. Colección de Historiadores de Chile, Documentos relativos a la Historia Nacional Tomo IX (tomo II).

Cisternas M., Carvajal M., Wesson R., Ely L., and Gorigoitia N., 2017, “Exploring the Historical Earthquakes Preceding the Giant 1960 Chile Earthquake in a Time-Dependent Seismogenic Zone", in Bulletin of the Seismological Society of America, Vol. 107, No. 6, pp. 2664-2675, December 2017, doi: 10.1785/0120170103.

Cisternas, M., F. Torrejón, and N. Gorigoitia (2012). Amending and complicating Chile's seismic catalog with the Santiago earthquake of 7 August 1580, J. S. Am. Earth Sci. 33, 102-109.

Dumont d'Urville, J. 1846. Voyage au Pole Sud et dans l'Océanie sur les corvettes l'Astrolabe et la Zelee. Gide et Cia. Editeurs, Atlas pittoresque, Tome I. París.

Gay, Claudio. Historia Física y Política de Chile. Documentos. Imprenta de E. Thunot y Ca, París, 1852, Vol. II, 526 pp. pp. 484-491.

Góngora Marmolejo, Alonso.1862. Historia de Chile desde su descubrimiento hasta el año de 1575. Colección de Historiadores de Chile y documentos relativos a la Historia Nacional, Tomo II, Historia de Góngora Marmolejo (1536-1575), Santiago, 1862. 
Juan, J. \& Ulloa, A. 1748. Relación histórica del viaje a la América Meridional. Imprenta de Antonio Marín, 3 Vols. Madrid.

Lomnitz, Cinna. 1970. Major earthquakes and tsunamis in Chile during the period 1535 to 1955. International Journal of Earth Sciences 59, 938-960.

Lomnitz, Cinna. 2004. Major earthquakes of Chile: a historical survey, 1535-1960. Seismological Research Letters 75, 368-378.

Mariño de Lovera, Pedro.1865. Crónica del Reino de Chile. Colección de Historiadores de Chile y documentos relativos a la Historia Nacional, Tomo VI, Santiago.

Medina, José Toribio. 1957. Colección de Documentos Inéditos para la Historia de Chile, Segunda Serie, vol. II 1573-1580, Fondo Histórico y Bibliográfico J. T. Medina, Santiago.

Montessus de Ballore, F. 1911. Historia sísmica de los Andes Meridionales al sur del paralelo XVI. Primera parte. Imprenta Cervantes, Santiago.

Montessus de Ballore, F 1912a. Historia sísmica de los Andes Meridionales al sur del paralelo XVI. Segunda parte. Imprenta Cervantes, Santiago.

Montessus de Ballore, F. 1912b. Historia sísmica de los Andes Meridionales al sur del paralelo XVI. Tercera parte. Imprenta Cervantes, Santiago.

Montessus de Ballore, F. 1912c. Historia sísmica de los Andes Meridionales al sur del paralelo XVI. Cuarta parte. Imprenta Cervantes, Santiago.

Montessus de Ballore, F. 1915. Historia sísmica de los Andes Meridionales al sur del paralelo XVI. Quinta parte, El terremoto del 16 de Agosto de 1906. Sociedad Imprenta-Litografía "Barcelona", SantiagoValparaíso.

Montessus de Ballore, F 1916. Historia sísmica de los Andes Meridionales al sur del paralelo XVI. Sexta parte, Adiciones. Sociedad Imprenta-Litografía "Barcelona", Santiago-Valparaíso.

Onetto Mauricio. 2007. "Entre aporías espaciales y sentidos náufragos: El terremoto de 1647 como catalizador de percepciones y asimilaciones históricas", en Nuevo mundo, mundos nuevos, No 7, París.

Publicaciones del Archivo Franciscano.1990. Relación sumaria de las cosas de la provincia de Chile, año 1584, en Orígenes de la orden Franciscana en Chile, vol. 13, Santiago de Chile, 1990, pp. 7-15.

Ramírez, Francisco Javier. 1994. Coronicón sacro-imperial de Chile, Santiago, Ediciones de la Dirección de Bibliotecas, Archivos y Museos, Centro de Investigaciones Diego Barros Arana, vol. I.

Rosales, Diego de. 1877. Historia general del reino Chile, Imprenta del Mercurio, Valparaíso. Tomo I. 
Appendix 1:

\begin{tabular}{|c|c|c|c|c|c|}
\hline \multicolumn{6}{|c|}{ TSUNAMI February 8th, 1570} \\
\hline Site & GPS L & ation & Tsunami & Water & Source \\
\hline Penco Hills & $-36.738569^{\circ}$ & $-72.997389^{\circ}$ & Yes & & $\begin{array}{l}\text { Pedro Mariño de Lovera, } \\
\text { "Crónica del Reino de Chile" } \\
\text { COLECHI, Tomo VI, } 1865 .\end{array}$ \\
\hline Penco Hills & $-36.738569^{\circ}$ & $-72.997389^{\circ}$ & Yes & & $\begin{array}{l}\text { Alonso de Góngora Marmolejo } \\
\text { "Historia de Chile desde su } \\
\text { descubrimiento hasta el año de } \\
\text { 1575". COLECHI, Tomo II, } 1862 .\end{array}$ \\
\hline Penco Hills & $-36.738569^{\circ}$ & $-72.997389^{\circ}$ & Yes & & $\begin{array}{l}\text { Diego de Rosales, Historia } \\
\text { general del reino Chile, } \\
\text { Imprenta del Mercurio, } \\
\text { Valparaíso, 1877, Tomo I }\end{array}$ \\
\hline Plaza Penco & $-36.738486^{\circ}$ & $-72.997370^{\circ}$ & Yes & $3-4 M$ & Idem. \\
\hline $\begin{array}{l}\text { La Merced } \\
\text { Convento }\end{array}$ & $-36.741625^{\circ}$ & $-72.991975^{\circ}$ & Yes & & $\begin{array}{c}\text { Francisco Javier Ramírez, } \\
\text { "Coronicón sacro-imperial de } \\
\text { Chile. Santiago, Ediciones de la } \\
\text { DIBAM \&, Centro de } \\
\text { Investigaciones Diego Barros } \\
\text { Arana, 1994, vol. 1, }\end{array}$ \\
\hline Town Fort & $-36.737872^{\circ}$ & $-72.994308^{\circ}$ & Yes & & $\begin{array}{l}\text { Pedro Mariño de Lovera, } \\
\text { "Crónica del Reino de Chile" } \\
\text { COLECHI, Tomo VI, } 1865 .\end{array}$ \\
\hline $\begin{array}{c}\text { Laguna } \\
\text { Cantarranas }\end{array}$ & $-36.736044^{\circ}$ & $-72.991631^{\circ}$ & Yes & & $\begin{array}{l}\text { Alonso de Góngora Marmolejo } \\
\text { "Historia de Chile desde su } \\
\text { descubrimiento hasta el año de } \\
\text { 1575". COLECHI, Tomo II, } 1862 .\end{array}$ \\
\hline $\begin{array}{l}\text { Old San } \\
\text { Francisco } \\
\text { Convent }\end{array}$ & $-36.730993^{\circ}$ & $-72.990132^{\circ}$ & No & & $\begin{array}{c}\text { Publicaciones del Archivo } \\
\text { Franciscano, Relación sumaria } \\
\text { de las cosas de la provincia de } \\
\text { Chile, año 1584, en Orígenes } \\
\text { de la orden Franciscana en } \\
\text { Chile, vol. 13, Santiago de } \\
\text { Chile, } 1990 .\end{array}$ \\
\hline
\end{tabular}


Appendix 2:

\begin{tabular}{|c|c|c|c|c|c|}
\hline \multicolumn{6}{|c|}{ TSUNAMI December 16th, 1575} \\
\hline Site & GPS L & ation & Tsunami & Water & Source \\
\hline $\begin{array}{l}\text { Melchor } \\
\text { Calderón }\end{array}$ & $-36.737800^{\circ}$ & $-72.995372^{\circ}$ & Yes & & $\begin{array}{c}\text { José Toribio Medina, Colección } \\
\text { de Documentos Inéditos para la } \\
\text { Historia de Chile, Segunda Serie, } \\
\text { vol. II 1573-1580, Fondo } \\
\text { Histórico y Bibliográfico J. T. } \\
\text { Medina, Santiago, } 1957 .\end{array}$ \\
\hline $\begin{array}{c}\text { San } \\
\text { Francisco } \\
\text { Convent }\end{array}$ & $-36.737872^{\circ}$ & $-72.994308^{\circ}$ & Yes & $1,5-2 M$ & $\begin{array}{c}\text { Publicaciones del Archivo } \\
\text { Franciscano, Relación sumaria de } \\
\text { las cosas de la provincia de Chile, } \\
\text { año } 1584 \text {, en Orígenes de la } \\
\text { orden Franciscana en Chile, vol. } \\
\text { 13, Santiago de Chile, } 1990 .\end{array}$ \\
\hline
\end{tabular}

Appendix 3:

\begin{tabular}{|c|c|c|c|c|c|}
\hline \multicolumn{2}{|c|}{ TSUNAMI March 15th, 1657 } \\
\hline Site & \multicolumn{2}{|c|}{ GPS Location } & $\begin{array}{c}\text { Tsunami } \\
\text { Damage }\end{array}$ & $\begin{array}{c}\text { Water } \\
\text { Depth }\end{array}$ & Source \\
\hline $\begin{array}{c}\text { Santo Domingo } \\
\text { Convent }\end{array}$ & $-36.738800^{\circ}$ & $-72.999581^{\circ}$ & Yes & & $\begin{array}{c}\text { Archivo provincial } \\
\text { dominico, Libro con Reales } \\
\text { Cédulas. Años 1589- } \\
\text { 1695. 06/A6, pp. 268-270 }\end{array}$ \\
\hline $\begin{array}{c}\text { La Merced } \\
\text { Convento }\end{array}$ & $-36.741625^{\circ}$ & $-72.991975^{\circ}$ & No & & $\begin{array}{c}\text { Francisco Javier Ramírez, } \\
\text { "Coronicón sacro-imperial } \\
\text { de Chile. Santiago, } \\
\text { Ediciones de la DIBAM \&, } \\
\text { Centro de Investigaciones } \\
\text { Diego Barros Arana, 1994, } \\
\text { vol. 1. }\end{array}$ \\
\hline
\end{tabular}




\begin{tabular}{|c|c|c|c|c|c|}
\hline Penco Catedral & $-36.738814^{\circ}$ & $-72.997992^{\circ}$ & Yes & $\begin{array}{c}30 \mathrm{~cm}- \\
1,5 \mathrm{M}\end{array}$ & $\begin{array}{l}\text { Vicente Carvallo } \\
\text { Goyeneche, Descripcion } \\
\text { Historico-Jeografica del } \\
\text { reino de Chile Colección de } \\
\text { Historiadores de Chile, } \\
\text { Documentos relativos a la } \\
\text { Historia Nacional Tomo IX } \\
\text { (tomo II). }\end{array}$ \\
\hline Penco River & $-36.736736^{\circ}$ & $-72.995438^{\circ}$ & Yes & & $\begin{array}{l}\text { Diego de Rosales, Historia } \\
\text { general del reino Chile, } \\
\text { Imprenta del Mercurio, } \\
\text { Valparaíso, 1877, Tomo I }\end{array}$ \\
\hline $\begin{array}{c}\text { San Agustín } \\
\text { Convent }\end{array}$ & $-36.736744^{\circ}$ & $-72.992125^{\circ}$ & Yes & $3-4 M$ & Ibídem \\
\hline Jesuita Chapel & $-36.738813^{\circ}$ & $-72.996345^{\circ}$ & Yes & & Ibídem \\
\hline Jesuita Colegio & $-36.738717^{\circ}$ & $-72.995924^{\circ}$ & Yes & & Ibídem \\
\hline $\begin{array}{c}\text { Laguna } \\
\text { Cantarranas }\end{array}$ & $-36.736044^{\circ}$ & $-72.991631^{\circ}$ & Yes & & Ibídem \\
\hline $\begin{array}{c}\text { María Gatica } \\
\text { Aranda }\end{array}$ & $-36.738606^{\circ}$ & $-72.998997^{\circ}$ & Yes & & Ibídem \\
\hline Palacio Real & $-36.738457^{\circ}$ & $-72.995100^{\circ}$ & Yes & & Ibídem \\
\hline $\begin{array}{c}\text { San Francisco } \\
\text { Convent }\end{array}$ & $-36.737872^{\circ}$ & $-72.994308^{\circ}$ & Yes & & Ibídem \\
\hline $\begin{array}{c}\text { Hospital San Juan } \\
\text { de Dios }\end{array}$ & $-36.737419^{\circ}$ & $-72.995742^{\circ}$ & Yes & & Ibídem \\
\hline Oficina Veedor & $-36.737431^{\circ}$ & $-72.996592^{\circ}$ & Yes & & Ibídem \\
\hline Oficina Municiones & $-36.737189^{\circ}$ & $-72.996739^{\circ}$ & Yes & & Ibídem \\
\hline Oficina Caja Real & $-36.737272^{\circ}$ & $-72.996422^{\circ}$ & Yes & & Ibídem \\
\hline Guarnición Penco & $-36.737800^{\circ}$ & $-72.995372^{\circ}$ & Yes & & Ibídem \\
\hline Playa-Marina & $-36.734606^{\circ}$ & $-72.996048^{\circ}$ & Yes & & Ibídem \\
\hline $\begin{array}{c}\text { Cristóbal de la } \\
\text { Cerda }\end{array}$ & $-36.739169^{\circ}$ & $-72.990069^{\circ}$ & No & & ANH.JES vol. 71 \\
\hline Cabildo Penco & $-36.738350^{\circ}$ & $-72.996700^{\circ}$ & Yes & & ANH.JES vol. 71 \\
\hline $\begin{array}{c}\text { Luis del Castillo } \\
\text { Velasco }\end{array}$ & $-36.739997^{\circ}$ & $-72.998261^{\circ}$ & No & & ANH.RA vol. 72 \\
\hline $\begin{array}{c}\text { Rodrigo Arias de } \\
\text { Umaña }\end{array}$ & $-36.738194^{\circ}$ & $-72.997692^{\circ}$ & Yes & & ANH.RA vol. 72 \\
\hline $\begin{array}{l}\text { Jerónimo Mejia } \\
\text { Reinoso }\end{array}$ & $-36.739342^{\circ}$ & $-72.994583^{\circ}$ & Yes & & ANH.RA vol. 72 \\
\hline Francisco Minaya & $-36.739719^{\circ}$ & $-72.999031^{\circ}$ & Yes & & ANH.RA vol. 240 \\
\hline Alejandre Candia & $-36.738075^{\circ}$ & $-72.996283^{\circ}$ & Yes & & ANH.FV vol. 258 \\
\hline Lucas Montemayor & $-36.739658^{\circ}$ & $-72.998514^{\circ}$ & Yes & & ANH.ES vol. 294 \\
\hline
\end{tabular}




\begin{tabular}{|c|c|c|c|c|}
\hline Juana Moncada & $-36.736869^{\circ}$ & $-72.993836^{\circ}$ & Yes & ANH.RA vol. 301 \\
\hline $\begin{array}{c}\text { Ambrosio Jimenez } \\
\text { Rivera }\end{array}$ & $-36.738192^{\circ}$ & $-72.992911^{\circ}$ & Yes & ANH.RA vol. 544 \\
\hline Bartolomé Bustos & $-36.740914^{\circ}$ & $-72.993789^{\circ}$ & No & ANH.RA vol. 872 \\
\hline Juan Quiñones & $-36.738800^{\circ}$ & $-72.994908^{\circ}$ & Yes & ANH.RA vol. 927 \\
\hline Alonso Puga Novoa & $-36.740511^{\circ}$ & $-72.994014^{\circ}$ & Yes & ANH.RA vol. 1188 \\
\hline $\begin{array}{c}\text { Tienda Lázaro San } \\
\text { Martin }\end{array}$ & $-36.738542^{\circ}$ & $-72.996172^{\circ}$ & Yes & ANH.RA vol. 1201 \\
\hline Pedro Gallegos & $-36.738467^{\circ}$ & $-72.995936^{\circ}$ & Yes & ANH.RA vol. 1201 \\
\hline Lázaro San Martin & $-36.736817^{\circ}$ & $-72.993656^{\circ}$ & Yes & ANH.RA vol. 1201 \\
\hline Penco Plaza & $-36.738569^{\circ}$ & $-72.997389^{\circ}$ & Yes & ANH.RA vol. 1201 \\
\hline $\begin{array}{c}\text { Francisco } \\
\text { Villaseñor Acuña }\end{array}$ & $-36.739083^{\circ}$ & $-72.995656^{\circ}$ & No & ANH.RA vol. 1868 \\
\hline $\begin{array}{c}\text { Bartolomé Nuñez } \\
\text { de Leon }\end{array}$ & $-36.735903^{\circ}$ & $-72.993311^{\circ}$ & Yes & ANH.RA vol. 2201 \\
\hline $\begin{array}{c}\text { Juan Valiente de la } \\
\text { Barra }\end{array}$ & $-36.739147^{\circ}$ & $-72.999325^{\circ}$ & Yes & ANH.RA vol. 2692 \\
\hline Laureano Vera & $-36.738386^{\circ}$ & $-72.993461^{\circ}$ & Yes & Carta MM 2712 \\
\hline
\end{tabular}

Appendix 4:

\begin{tabular}{|c|c|c|c|c|c|}
\hline \multicolumn{2}{|c|}{ TSUNAMI May 24th, 1733 } \\
\hline Site & \multicolumn{2}{|c|}{ GPS Location } & $\begin{array}{c}\text { Tsunami } \\
\text { Damage }\end{array}$ & $\begin{array}{c}\text { Water } \\
\text { Depth }\end{array}$ & Source \\
\hline $\begin{array}{c}\text { San } \\
\text { Francisco } \\
\text { Convent }\end{array}$ & $-36.737872^{\circ}$ & $-72.994308^{\circ}$ & Yes & & $\begin{array}{c}\text { ANH.CMI vol. 4364, fojas 23- } \\
29 v\end{array}$ \\
\hline $\begin{array}{c}\text { Hospital San } \\
\text { Juan de Dios }\end{array}$ & $-36.737419^{\circ}$ & $-72.995742^{\circ}$ & Yes & & Ibídem \\
\hline $\begin{array}{c}\text { Playa- } \\
\text { Marina }\end{array}$ & $-36.734606^{\circ}$ & $-72.996048^{\circ}$ & Yes & & Ibídem \\
\hline
\end{tabular}


Appendix 5:

\begin{tabular}{|c|c|c|c|c|c|}
\hline \multicolumn{6}{|c|}{ TSUNAMI July 8th, 1730} \\
\hline Site & \multicolumn{2}{|c|}{ GPS Location } & \multirow{2}{*}{$\begin{array}{c}\text { Tsunami } \\
\text { Damage }\end{array}$} & \multirow{2}{*}{$\begin{array}{l}\text { Water } \\
\text { Depth }\end{array}$} & Source \\
\hline Joseph Obando & $-36.741503^{\circ}$ & $-72.993300^{\circ}$ & & & $\begin{array}{l}\text { Apuntes varios: presidio } \\
\text { de Valdivia, Hacienda de } \\
\text { Llaullau, terremoto de } \\
1730 \text { y salida de mar. } \\
\text { Archivo Nacional } \\
\text { Histórico de Chile, Fondo } \\
\text { Claudio Gay, Vol. 18, } \\
\text { fojas } 162 \mathrm{v}-164 \mathrm{v} .\end{array}$ \\
\hline Puente Merced & $-36.740589^{\circ}$ & $-72.993514^{\circ}$ & Yes & & Ibídem \\
\hline $\begin{array}{l}\text { La Planchada } \\
\text { Penco }\end{array}$ & $-36.736631^{\circ}$ & $-72.995925^{\circ}$ & Yes & & Ibídem \\
\hline $\begin{array}{c}\text { Joseph García de } \\
\text { Sobarzo }\end{array}$ & $-36.738272^{\circ}$ & $-72.998178^{\circ}$ & Yes & & Ibídem \\
\hline $\begin{array}{c}\text { Pedro López de } \\
\text { Asencio }\end{array}$ & $-36.739642^{\circ}$ & $-72.993642^{\circ}$ & Yes & & Ibídem \\
\hline Puente Hospital & $-36.737464^{\circ}$ & $-72.995197^{\circ}$ & Yes & & Ibídem \\
\hline Palacio Obispo & $-36.737505^{\circ}$ & $-72.997101^{\circ}$ & Yes & & Ibídem \\
\hline Puente Palacio & $-36.738478^{\circ}$ & $-72.994608^{\circ}$ & Yes & & Ibídem \\
\hline Penco River & $-36.736736^{\circ}$ & $-72.995438^{\circ}$ & Yes & & Ibídem \\
\hline Penco Plaza & $-36.738569^{\circ}$ & $-72.997389^{\circ}$ & Yes & & Ibídem \\
\hline Penco San Agustín & $-36.736744^{\circ}$ & $-72.992125^{\circ}$ & Yes & & Ibídem \\
\hline $\begin{array}{c}\text { Laguna } \\
\text { Cantarranas }\end{array}$ & $-36.736044^{\circ}$ & $-72.991631^{\circ}$ & Yes & & Ibídem \\
\hline Palacio Real Penco & $-36.738457^{\circ}$ & $-72.995100^{\circ}$ & Yes & $>1 \mathrm{M}$ & Ibídem \\
\hline Oficina Veedor & $-36.737431^{\circ}$ & $-72.996592^{\circ}$ & Yes & & Ibídem \\
\hline Oficina Municiones & $-36.737189^{\circ}$ & $-72.996739^{\circ}$ & Yes & & Ibídem \\
\hline Oficina Caja Real & $-36.737272^{\circ}$ & $-72.996422^{\circ}$ & Yes & & Ibídem \\
\hline $\begin{array}{c}\text { Hospital San Juan } \\
\text { de Dios }\end{array}$ & $-36.737419^{\circ}$ & $-72.995742^{\circ}$ & Yes & & Ibídem \\
\hline Guarnición Penco & $-36.737800^{\circ}$ & $-72.995372^{\circ}$ & Yes & & Ibídem \\
\hline Ventura Bello & $-36.739342^{\circ}$ & $-72.994583^{\circ}$ & Yes & & Ibídem \\
\hline Cabildo Penco & $-36.738350^{\circ}$ & $-72.996700^{\circ}$ & Yes & & Ibídem \\
\hline
\end{tabular}




\begin{tabular}{|c|c|c|c|c|c|}
\hline Seminario San José & $-36.739092^{\circ}$ & $-72.997086^{\circ}$ & No & & $\begin{array}{c}\text { Archivum Romanum } \\
\text { Societatis lesu (Roma), } \\
\text { Provincia Chilensis, vol. } 5 \\
\text { (“Chilensis historia, 1592- } \\
\text { 1766" y “Varia Acta, } \\
\text { 1624-1770”, pieza 78, } \\
\text { fojas 304-314v. }\end{array}$ \\
\hline Tiendas Plaza & $-36.738064^{\circ}$ & $-72.996622^{\circ}$ & Yes & & Ibídem \\
\hline $\begin{array}{l}\text { Penco Jesuita } \\
\text { Capilla }\end{array}$ & $-36.738813^{\circ}$ & $-72.996345^{\circ}$ & Yes & $0,8 \mathrm{M}$ & Ibídem \\
\hline $\begin{array}{c}\text { Penco Jesuita } \\
\text { Colegio }\end{array}$ & $-36.738717^{\circ}$ & $-72.995924^{\circ}$ & Yes & $0,8 \mathrm{M}$ & Ibídem \\
\hline $\begin{array}{c}\text { San Francisco } \\
\text { Penco }\end{array}$ & $-36.737872^{\circ}$ & $-72.994308^{\circ}$ & Yes & $>1,6 \mathrm{M}$ & Ibídem \\
\hline Playa-Marina & $-36.734606^{\circ}$ & $-72.996048^{\circ}$ & Yes & $8,3 \mathrm{M}$ & Ibídem \\
\hline Capilla La Hermita & $-36.743406^{\circ}$ & $-72.995260^{\circ}$ & No & & $\begin{array}{l}\text { "Expediente relativo a las } \\
\text { ruinas causadas en Chile } \\
\text { por el terremoto que } \\
\text { sufrió en } 1730 " . \text { Archivo } \\
\text { General de Indias, } \\
\text { Audiencia de Chile; Chile, } \\
145 / 1731- \\
\text { 1740/Inventario de la } \\
\text { sección de Chile }\end{array}$ \\
\hline Penco Catedral & $-36.738814^{\circ}$ & $-72.997992^{\circ}$ & Yes & & Ibídem \\
\hline $\begin{array}{l}\text { Convento Santo } \\
\text { Domingo Penco }\end{array}$ & $-36.738800^{\circ}$ & $-72.999581^{\circ}$ & No & & Ibídem \\
\hline La Merced Penco & $-36.741625^{\circ}$ & $-72.991975^{\circ}$ & No & & Ibídem \\
\hline $\begin{array}{c}\text { Gabriela de la } \\
\text { Barra }\end{array}$ & $-36.739858^{\circ}$ & $-72.994314^{\circ}$ & Yes & & ANH.RA vol. 80 \\
\hline $\begin{array}{c}\text { Alonso Córdova } \\
\text { Figueroa }\end{array}$ & $-36.738194^{\circ}$ & $-72.997692^{\circ}$ & Yes & & ANH.RA vol. 154 \\
\hline $\begin{array}{c}\text { Antonio González } \\
\text { Barriga }\end{array}$ & $-36.738306^{\circ}$ & $-72.999650^{\circ}$ & Yes & & ANH.RA vol. 154 \\
\hline Marcela Quiñones & $-36.738800^{\circ}$ & $-72.994908^{\circ}$ & Yes & & ANH.RA vol. 927 \\
\hline $\begin{array}{l}\text { Juan Francisco } \\
\text { González Estrada }\end{array}$ & $-36.739203^{\circ}$ & $-72.992356^{\circ}$ & Yes & & ANH.RA vol. 1290 \\
\hline $\begin{array}{c}\text { Tienda Ignacio } \\
\text { Mier }\end{array}$ & $-36.738064^{\circ}$ & $-72.996622^{\circ}$ & Yes & & ANH.RA vol. 1376 \\
\hline
\end{tabular}




\begin{tabular}{|c|c|c|c|c|c|}
\hline Felipe Antonio & $-36.735806^{\circ}$ & $-72.991211^{\circ}$ & Yes & ANH.RA vol. 1466 \\
\hline $\begin{array}{c}\text { Tomas Zúñiga } \\
\text { Carrasco }\end{array}$ & $-36.737131^{\circ}$ & $-72.988975^{\circ}$ & No & ANH.RA vol. 1466 \\
\hline Joseph Araya & $-36.737619^{\circ}$ & $-72.989217^{\circ}$ & No & ANH.RA vol. 1466 \\
\hline $\begin{array}{c}\text { Catalina Sánchez } \\
\text { Amaya }\end{array}$ & $-36.737700^{\circ}$ & $-72.988897^{\circ}$ & No & ANH.RA vol. 1466 \\
\hline $\begin{array}{c}\text { Juan Antonio } \\
\text { Espineda }\end{array}$ & $-36.737322^{\circ}$ & $-72.995500^{\circ}$ & Yes & ANH.RA vol. 1554 \\
\hline Carlos Mol & $-36.739547^{\circ}$ & $-72.997036^{\circ}$ & No & & ANH.RA vol. 1591 \\
\hline
\end{tabular}

Appendix 6:

\begin{tabular}{|c|c|c|c|c|c|}
\hline \multicolumn{6}{|c|}{ TSUNAMI May 25th, 1751} \\
\hline Site & \multicolumn{2}{|c|}{ GPS Location } & \multirow{2}{*}{$\begin{array}{c}\text { Tsunami } \\
\text { Damage }\end{array}$} & \multirow{2}{*}{$\begin{array}{l}\text { Water } \\
\text { Depth }\end{array}$} & Source \\
\hline Juan Arechavala & $-36.738958^{\circ}$ & $-72.998722^{\circ}$ & & & $\begin{array}{c}\text { Cartas edificantes y } \\
\text { curiosas escritas de las } \\
\text { misiones extranjeras y } \\
\text { de levante por algunos } \\
\text { misioneros de la } \\
\text { Compañía de Jesús, } \\
\text { Tomo XV, Madrid, 1756, } \\
\text { pp. 406-422 }\end{array}$ \\
\hline Penco Jesuita Capilla & $-36.738813^{\circ}$ & $-72.996345^{\circ}$ & Yes & $2,1 \mathrm{M}$ & Ibídem \\
\hline Cantarranas & $-36.736044^{\circ}$ & $-72.991631^{\circ}$ & Yes & & Ibídem \\
\hline Plaza Penco & $-36.738486^{\circ}$ & $-72.997370^{\circ}$ & Yes & $3,3 \mathrm{M}$ & Ibídem \\
\hline La Merced Penco & $-36.741625^{\circ}$ & $-72.991975^{\circ}$ & Yes & & Ibídem \\
\hline San Francisco Penco & $-36.737872^{\circ}$ & $-72.994308^{\circ}$ & Yes & $4 \mathrm{M}$ & Ibídem \\
\hline Juan Saralegui & $-36.738064^{\circ}$ & $-72.996622^{\circ}$ & Yes & & Ibídem \\
\hline $\begin{array}{c}\text { Royal Treasurer y } \\
\text { Quatermaster }\end{array}$ & $-36.741728^{\circ}$ & $-72.992711^{\circ}$ & Yes & & Ibídem \\
\hline Calle Santo Domingo & $-36.741243^{\circ}$ & $-72.998301^{\circ}$ & Yes & & Ibídem \\
\hline Penco River & $-36.736736^{\circ}$ & $-72.995438^{\circ}$ & Yes & & BN.MM 4268 \\
\hline Penco Plaza & $-36.738569^{\circ}$ & $-72.997389^{\circ}$ & Yes & & BN.MM 4268 \\
\hline Penco Catedral & $-36.738814^{\circ}$ & $-72.997992^{\circ}$ & Yes & & BN.MM 4268 \\
\hline Penco San Agustín & $-36.736744^{\circ}$ & $-72.992125^{\circ}$ & Yes & & BN.MM 4268 \\
\hline Penco Jesuita Colegio & $-36.738717^{\circ}$ & $-72.995924^{\circ}$ & Yes & & BN.MM 4268 \\
\hline Cabildo Penco & $-36.738350^{\circ}$ & $-72.996700^{\circ}$ & Yes & & BN.MM 4268 \\
\hline
\end{tabular}




\begin{tabular}{|c|c|c|c|c|c|}
\hline Palacio Real Penco & $-36.738457^{\circ}$ & $-72.995100^{\circ}$ & Yes & & BN.MM 4268 \\
\hline La Merced Penco & $-36.741625^{\circ}$ & $-72.991975^{\circ}$ & Yes & & BN.MM 4268 \\
\hline Capilla La Hermita & $-36.743406^{\circ}$ & $-72.995260^{\circ}$ & No & & BN.MM 4268 \\
\hline $\begin{array}{l}\text { Hospital San Juan de } \\
\text { Dios }\end{array}$ & $-36.737419^{\circ}$ & $-72.995742^{\circ}$ & Yes & & BN.MM 4268 \\
\hline Palacio Obispo & $-36.737505^{\circ}$ & $-72.997101^{\circ}$ & Yes & & BN.MM 4268 \\
\hline $\begin{array}{l}\text { Convento Santo } \\
\text { Domingo Penco }\end{array}$ & $-36.738800^{\circ}$ & $-72.999581^{\circ}$ & Yes & & BN.MM 4268 \\
\hline Oficina Veedor & $-36.737431^{\circ}$ & $-72.996592^{\circ}$ & Yes & & AGI Chile 146 \\
\hline Oficina Municiones & $-36.737189^{\circ}$ & $-72.996739^{\circ}$ & Yes & & AGI Chile 146 \\
\hline Oficina Caja Real & $-36.737272^{\circ}$ & $-72.996422^{\circ}$ & Yes & & AGI Chile 146 \\
\hline La Planchada Penco & $-36.736631^{\circ}$ & $-72.995925^{\circ}$ & Yes & & AGI Chile 146 \\
\hline Guarnición Penco & $-36.737800^{\circ}$ & $-72.995372^{\circ}$ & Yes & & AGI Chile 146 \\
\hline Playa-Marina & $-36.734606^{\circ}$ & $-72.996048^{\circ}$ & Yes & $16 \mathrm{M}$ & $\begin{array}{c}\text { Gay, Claudio. Historia } \\
\text { Física y Política de Chile. } \\
\text { Documentos. Imprenta } \\
\text { de E. Thunot y Ca, París, } \\
\text { 1852, Vol. II, } 526 \text { pp. } \\
\text { 484-491. }\end{array}$ \\
\hline Playa-Marina & $-36.734606^{\circ}$ & $-72.996048^{\circ}$ & Yes & & $\begin{array}{c}\text { 1842, Paris, Dumont } \\
\text { d'Urville }\end{array}$ \\
\hline $\begin{array}{c}\text { Juana Guzmán } \\
\text { Espinoza }\end{array}$ & $-36.740511^{\circ}$ & $-72.994014^{\circ}$ & Yes & & ANH.NC vol. 1 \\
\hline Antonio Cerecedo & $-36.737672^{\circ}$ & $-72.989281^{\circ}$ & Yes & & ANH.RA vol. 2468 \\
\hline
\end{tabular}

Appendix 7:

\begin{tabular}{|c|c|c|c|c|c|}
\hline \multicolumn{6}{|c|}{ TSUNAMI February 20th, 1835} \\
\hline Site & \multicolumn{2}{|c|}{ GPS Location } & \multirow{2}{*}{$\begin{array}{c}\text { Tsunami } \\
\text { Damage } \\
\text { Yes }\end{array}$} & \multirow{2}{*}{$\begin{array}{l}\text { Water } \\
\text { Depth }\end{array}$} & \multirow{2}{*}{\begin{tabular}{|c|} 
Source \\
$\begin{array}{l}\text { 1842, Paris, Dumont } \\
\text { d'Urville }\end{array}$ \\
\end{tabular}} \\
\hline Penco River & $-36.736736^{\circ}$ & $-72.995438^{\circ}$ & & & \\
\hline Penco Plaza & $-36.738569^{\circ}$ & $-72.997389^{\circ}$ & Yes & & Ibídem \\
\hline Penco Catedral & $-36.738814^{\circ}$ & $-72.997992^{\circ}$ & Yes & & Ibídem \\
\hline Cantarranas & $-36.736044^{\circ}$ & $-72.991631^{\circ}$ & Yes & & Ibídem \\
\hline $\begin{array}{l}\text { Convento Santo } \\
\text { Domingo Penco }\end{array}$ & $-36.738800^{\circ}$ & $-72.999581^{\circ}$ & Yes & & Ibídem \\
\hline San Francisco Penco & $-36.737872^{\circ}$ & $-72.994308^{\circ}$ & Yes & & Ibídem \\
\hline
\end{tabular}




\begin{tabular}{|c|c|c|c|c|c|}
\hline $\begin{array}{c}\text { Hospital San Juan de } \\
\text { Dios }\end{array}$ & $-36.737419^{\circ}$ & $-72.995742^{\circ}$ & Yes & & Ibídem \\
\hline Molino Penco & $-36.737800^{\circ}$ & $-72.995372^{\circ}$ & Yes & & Ibídem \\
\hline Playa-Marina & $-36.734606^{\circ}$ & $-72.996048^{\circ}$ & Yes & $>3 \mathrm{M}$ & Ibídem \\
\hline La Planchada Penco & $-36.736631^{\circ}$ & $-72.995925^{\circ}$ & Yes & & Ibídem \\
\hline
\end{tabular}

